Bindu Swetha Pasuluri, Daniel C, D.S. Vijayan, S. Arvindan, S. Pradeep Kumar

Editors

\title{
Innovative Teaching and Learning Process during COVID 19
}

$2^{\text {nd }}$ Edition 


\section{Editor}

Bindu Swetha Pasuluri,

Daniel C,

D. S. Vijayan,

S. Arvindan,

S. Pradeep Kumar

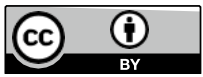

ISBN 978-93-89631-66-1

ISBN (eBook) 978-93-89631-67-8

https://doi.org/10.34256/iorip203

(C) IOR INTERNATIONAL PRESS. This book is an open access publication. Open Access This book is licensed under the terms of the Creative Commons Attribution 4.0 International License (http://creativecommons.org/licenses/by/4.0/), which permits use, sharing, adaptation, distribution and reproduction in any medium or format, as long as you give appropriate credit to the original author(s) and the source, provide a link to the Creative Commons license and indicate if changes were made.

The images or other third party material in this book are included in the book's Creative Commons license, unless indicated otherwise in a credit line to the material. If material is not included in the book's Creative Commons license and your intended use is not permitted by statutory regulation or exceeds the permitted use, you will need to obtain permission directly from the copyright holder. The use of general descriptive names, registered names, trademarks, service marks, etc. in this publication does not imply, even in the absence of a specific statement, that such names are exempt from the relevant protective laws and regulations and therefore free for general use.

The publisher, the authors and the editors are safe to assume that the advice and information in this book are believed to be true and accurate at the date of publication. Neither the publisher nor the authors or the editors give a warranty, expressed or implied, with respect to the material contained herein or for any errors or omissions that may have been made. The publisher remains neutral with regard to jurisdictional claims in published maps and institutional affiliations.

This IOR INTERNATIONAL PRESS imprint is published by the registered company IOR PRESS. The registered company address is: 5/11, Perumal Kovil Street, Naickenpalayam, Coimbatore641020 Tamil Nadu, India. 


\section{About the Editors}

Ms. Bindu Swetha Pasuluri, an Innovator, Assistant Professor, from Department of Electronics \& Communication Engineering, G Pullaiah College of Engineering and Technology, Kurnool, Andhra Pradesh, India.

Mr. Daniel C, Research Scholar, from Department of Civil Engineering, Karunya Institute of Technology and Sciences, Coimbatore and Founder, Manuscriptpedia, Kanyakumari.

Dr. D. S. Vijayan, Associate Professor, Department of Civil Engineering, Aarupadai Veedu Institute of Technology, VMRF, Chennai, India

Mr. S. Arvindan, Assistant professor, Anand school of Architecture and Research scholar, Aarupadai Veedu Institute of Technology (AVIT), India

Mr. S. Pradeep Kumar, Assistant Professor and In-Charge Head, Department of Civil Engineering, College of Engineering and Technology, S. K. University, Ananthapuram, Andhra Pradesh, India

We 5 have a common intention to empower teaching and learning communities via innovative teaching practices during Covid 19. As teachers cum researchers, we create a common platform so that they could share their point of view in techniques to improve teaching and learning practices in India during Covid 19. 


\section{Summary}

The book on "Innovative Teaching and Learning Process during COVID 19" is a very good effort in bringing novel ideas at the time of pandemic. The engagement with academic fraternity leading to this wonderful outcome is laudable. As the editors of this book, we are fortunate to go through every article and found few interesting aspects in teaching and learning process.

Innovation has been the most buzzed word in the world today. In fact, academia across the globe are potentially involved in INNOVATION at every possible level. We wish this race with this pace towards innovation in teaching and learning mechanism drives us to "INNOVATION 5.0" in near future. This book will be instrumental in polarizing the thoughts of reader towards this process of innovation, particularly, in delivering lectures using online platforms and eresources.

The authors in this book touched upon diverse topics related to the paradigm shift in teaching and learning process. Various tools, innovative practices were presented vividly in the articles of this book. Congratulations and wishes to authors and publishers for bringing out this productive outcome in the most critical transition time of educational reforms. 


\section{Contents}

1. Improved Techniques for The Assessment of Online Learners............1

2. Teaching and Learning Process: A Transformation During Covid19.........................................................

3. Innovative and Creative Learning in Covid-19......................8

4. Different Ways COVID-19 Could Change How We Educate Future Generations.................................................. 9

5. Recent Teaching Techniques During Covid'19 - an Overview...........11

6. Kalam's India Vision 2020- Have We Reached the set Goals on

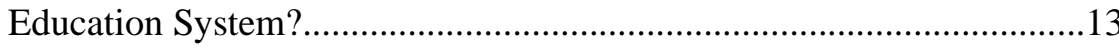

7. Teaching and Learning with Technology- E Learning Process...........16

8. A Perspective Study: Online Education/ Classes for Students to Aid During Covid-19 Pandemic....................................... 18

9. ICT Tools for Effective Learning and Better Placements..............20

10. Collaborative Teaching by Identifying Students Learning Style.........23

11. Trending Teaching and Learning Mechanisms in 21 st Century.........26

12. Innovative Teaching Learning Methods in Technical Courses During COVID Lockdown...............................................29

13. Scaling Online Teaching and Learning to Best Conventional Mode....31

14. Structuring and Implementing the Remote Learning Strategies During Covid-19.........................................................

15. Ingenious Approach of Technology Aided Knowledge Transfer in Prodigious Situations 
16. Challenges of COVID-19 in Higher Education in India...............42

17. Learning Keys During Lockdown..................................46

18. Teaching and Learning Software Environments Under Open Educational Resources..................................................49

19. Innovative and Effective Teaching Strategies for Online Education.....51

20. Modernization in Learning Practices \& Also Innovative Teaching......54

21. Effective and Innovative Online Teaching........................56

22. Innovative Teaching and Learning Process during COVID 19.........59

23. The key Element of online Teaching Learning Experiences............63

24. Scope for Bridging Industry-Academia Gap During Covid-19.........66

25. Industry and Academia Strategic Partnership for Skill Improvement with Multidisciplinary Method in Engineering Education a Novel Approach Afterward Covid-19..............................................69

26. An Innovative Practice for Interactive learning process during COVID-

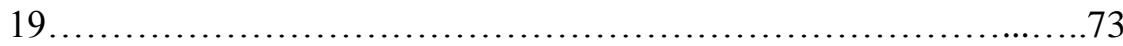

27. Advantages of Online Classes During Covid 19......................75

28. Teaching learning practices during lockdown......................76

29. A Study on Organizational Commitment Factors on Burnout among private school teachers in Kodaikanal................................77 


\title{
Improved Techniques for The Assessment of Online Learners
}

\author{
Ashish S. Bhaisare ${ }^{1, *}$, Anita V. Nikalje ${ }^{2}$ \\ ${ }^{1}$ Department of EXTC, Shivajirao S. Jondhle College of Engineering and \\ Technology, Shahapur, Asangaon, Dist. Thane, Maharashtra - 421601. \\ ${ }^{2}$ Department of EXTC, Deogiri Institute of Engineering and Management Studies, \\ Railway Station Road, Aurangabad, Maharashtra - 431005. \\ *Email: bhaisare.ashish@gmail.com
}

There is no doubt that online learning and the development of online courses is proliferating. The convenience of working online has proven to be very attractive to students and instructors alike. Despite its popularity, online learning is not without its challenges. As instructors are finding their way in the online environment and paying more attention to good course design and delivery, they are discovering that traditional forms of assessment of student work such as tests and quizzes that served them well in the face to face classroom may not work quite as well online. Milam, Voorhees, and Bedard - Voorhees (2004) note, "The online paradigm holds that learning itself may be different in the online environment and, if that is true, then the methodology for measuring it should also be different or should measure those things that are, in fact, different" effective assessment has come increased concern about academic honesty, raising questions like these:

- How do I, as the instructor, know that students really understand and can apply the material I' $m$ teaching if I can' $t$ sees them?

- How can I ensure that students won' $t$ cheat on exams or other assessments in my online course?

In these fields, assessment criteria cannot be too precise or rigid, as building arguments that provide new insights is the benchmark of good performance. Jones, Voorhees, and Paulson (2002) define competencies as "the combination of skills, abilities, and knowledge needed to perform a specific task". Competencies support the dynamic link between knowing and expressing. Once competencies are established, the next level of focus should be the development of course outcomes. Course outcomes are important in that they help students learn more effectively and make it clear what students can expect to gain from taking the course.

Collaborative effort helps learners achieve a deeper level of knowledge generation while moving from independence to interdependence, thus strengthening the foundation of an online learning community, which we believe is the vehicle through which the course should be delivered. By learning together in a learning community, students have the opportunity to extend and deepen their learning experience, test out new ideas by sharing them with a supportive group, and receive 
critical and constructive feedback.

The Teacher Accurately Demonstrates Knowledge of the Content Area and Approved Curriculum.

\begin{tabular}{|l|l|l|}
\hline \multicolumn{1}{|c|}{$\begin{array}{c}\text { Provisional } \\
\text { Leacher: I }\end{array}$} & \multicolumn{1}{c|}{$\begin{array}{c}\text { Professional } \\
\text { Teacher: } \\
\text { Level II }\end{array}$} & \multicolumn{1}{|c|}{$\begin{array}{l}\text { Master Teacher: } \\
\text { Level III }\end{array}$} \\
\hline $\begin{array}{l}\text { A. Utilizes and } \\
\text { enhances approved } \\
\text { curriculum. }\end{array}$ & $\begin{array}{l}\text { A. Enhances and } \\
\text { extends approved } \\
\text { curriculum. }\end{array}$ & $\begin{array}{l}\text { A. Contributes to the refinement and } \\
\text { development of the approved } \\
\text { curriculum. }\end{array}$ \\
\hline $\begin{array}{l}\text { B. Gives clear } \\
\text { explanations } \\
\text { relating to lesson } \\
\text { content and } \\
\text { procedures. }\end{array}$ & $\begin{array}{l}\text { B. Gives clear } \\
\text { explanations } \\
\text { relating to lesson } \\
\text { content and } \\
\text { procedures. }\end{array}$ & $\begin{array}{l}\text { B. Provides clear explanations } \\
\text { relating to lesson content and } \\
\text { procedures in multiple ways and is } \\
\text { aware of knowledge and } \\
\text { preconceptions that students can bring } \\
\text { to the subject. }\end{array}$ \\
\hline $\begin{array}{l}\text { C. Communicates } \\
\text { accurately in the } \\
\text { content area. }\end{array}$ & $\begin{array}{l}\text { C. Communicates } \\
\text { accurately in the } \\
\text { content area. }\end{array}$ & $\begin{array}{l}\text { C. Communicates accurately } \\
\text { in the content area and can create } \\
\text { multiple paths to the subject matter. }\end{array}$ \\
\hline $\begin{array}{l}\text { D. Shows } \\
\text { interrelatedness } \\
\text { of one content area } \\
\text { to another. }\end{array}$ & $\begin{array}{l}\text { D. Integrates other } \\
\text { subjects into the } \\
\text { content curriculum. }\end{array}$ & $\begin{array}{l}\text { D. Can articulate to students the } \\
\text { interrelatedness of the disciplines. }\end{array}$ \\
\hline
\end{tabular}

\section{Designing Effective Assessments for the Online Environment}

How can we design assessments that are clear, easy to understand, and likely to work in the online environment? Gaytan, Rasmussen and Northrup (2005) suggest a number of effective techniques that can be used to create assessments that work well in the online environment, including the following:

- The provision of regular, ongoing communication with and feedback to students as a means by which to embed assessment in the course itself.

- The inclusion of dynamic interaction, defined by the use of group work, collaboration, and a high level of interaction through discussion.

- The modification of traditional assessment tools, such as essays, discussion

- question responses, and projects that require demonstration of skill acquisition

- $\quad$ and problem - solving ability.

- The use of alternative assessments, such as performance - based assessments,

- $\quad$ authentic assessments, and the use of e - portfolios. 


\section{Key principles in online assessment}

- Design learner centered assessments that align with learner - centered activities and assignments.

- Construct courses that contain a variety of learning activities and assessment measures that tap various learning styles and inhibit the possibilities for plagiarism and cheating.

- $\quad$ Promote, use, and assess learner contributions to the discussion board.

- Provide prompt feedback on assessments and assignments.

- Consider tests and quizzes delivered online to be "open book" measures and develop them with this factor in mind.

- To make online assessments effective, include performance assessment, authentic assessment, projects, portfolios, self - assessments, peer assessments, and weekly assignments that include discussion assignments.

\section{Test and Quiz Development Conant: -}

1) Respondus. www.respondus.com Respondus is a software application that supports test and quiz development and provides test banks. It can be used with most course management systems. In addition, the company provides Study Mate Author, which allows for the construction of games and other course activities.

2) Lesson Builder. www.softchalk.com Lesson Builder is a content authoring tool that also allows for the creation of tests and quizzes to support the developed content. It can be used with any course management system.

3) ComputerAssessmentCentre.

http://caacentre.lboro.ac.uk/resources/web/onlres4.shtml This site highlights research completed on the use of computer-assisted assessment in universities in Great Britain. Many of the software applications cited are useful in the design and review of assessment activities.

4) Northern Arizona University Offi ce of Academic Assessment. www4.nau.edu/assessment/main/research/webtools.htm This site compiles and presents assessment tools and course evaluation tools, most of which are useable at no charge.

5) Caveon. $\quad$ www.caveon.com Caveon provides web - based security testing services for a fee.

6) Kryterion. www.kryteriononline.com Kryterion provides test development, security, and virtual proctoring services for a fee. 


\title{
Teaching and Learning Process: A Transformation During Covid-19
}

\author{
S. Ganesh kumaran ${ }^{1,}{ }^{*}$, P. Rajeswari ${ }^{2}$, C.R. Balamurugan ${ }^{3}$ \\ ${ }^{1}$ Department of Electrical and Electronics Engineering, Sri Manakula Vinayagar \\ Engineering College, Puducherry \\ ${ }^{2}$ Department of Humanities and Science, Sri Manakula Vinayagar Engineering \\ College, Puducherry \\ ${ }^{3}$ Department of Electrical and Electronics Engineering, Karpagam College of \\ Engineering, Coimbatore \\ "Email: ganeshphd4u@gmail.com
}

Teaching and learning process depends on both the teachers and the learners. Its completion is based on how the instructor/teacher lectures the subject clearly and also based on how far the learners are able to understand the concept. It is not a single way approach but a two-way process where it can be achieved by an interactive process. The main goal or objective of teaching is to make the learners to gain knowledge and basic understanding the subject and to experience the same in future. Teachers love to teach in a classroom environment where their expectation is to get the learners attention. Learners are also ready to learn only when they get interested towards the subject and the teacher who teaches. It is on the instructors hand to make the students to get interested and moreover when they teach in a traditional method of lecturing by using black board, it will not be effective and learning process will not be completed and achieved.

But now-a-days, modern teaching methodology have been used by adding different multimedia objects like Power Point Presentation, Videos, gif, animation extra to make the learns to understand in a better manner. Usage of visual aids makes the learners to be attentive and focusing on the concept becomes much easier. It is also more helpful for the instructors to explain the subject easier and it is a speech notes for the instructor.

This chapter analyses about the various teaching methodology which is in practice and widely used. There are three main interactive teaching methodologies:

i) Unidirectional way of communication

ii) Bidirectional way of communication with simulations interaction with the students.

iii) Bidirectional way of communication

\section{i) Unidirectional way of communication}

In this method, Instructor teaches in a class room environment where the students are in passive mode, they only receive the information and understand the 
concept. They are not raising questions or not giving any response. This happens due to their nervousness, fear, and closed mindedness.
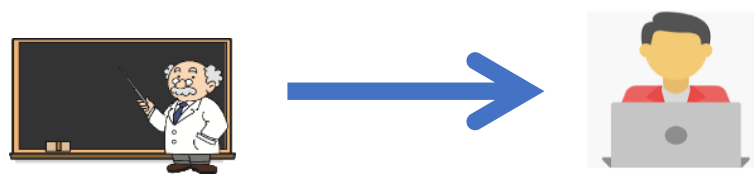

It is not highly recommended, because it will not give more output of understanding to students and the instructors are not able to assess the students properly. This passive teaching sometimes gives boredom to the learners and they are not able to concentrate and pay attention.

\section{ii) Bidirectional way of communication with simultaneous}

\section{interaction with the students}

In this method, the learners interact with the instructors immediately without any hesitation which is highly appreciated. But when the learners interrupt in the middle of the teaching, it creates a sort of disturbance to other learners. Sometimes it may give irritation to both the instructor or to the other learners. Hence, this is not advisable too for teaching learning process.
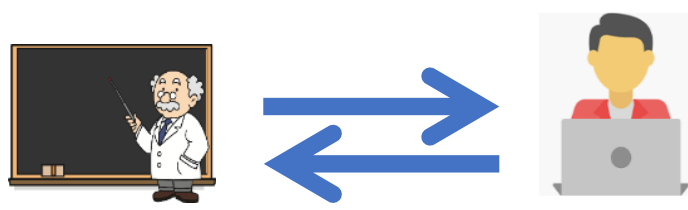

\section{iii) Bidirectional Way of Communication with Simulations}

\section{Interaction with The Students}
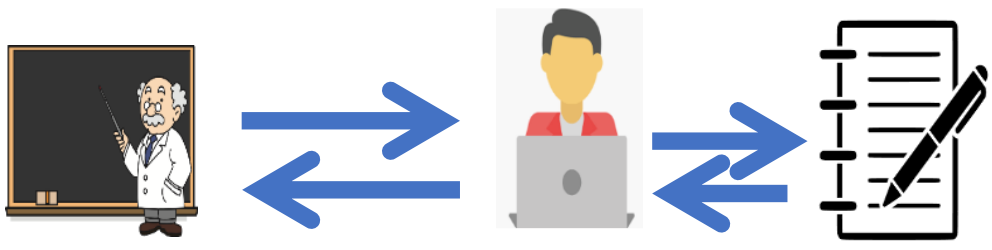

This method differs from the other two methodology of teaching learning process. Here, the instructor explains the concept clearly and the learners are more attentive throughout the session. The instructor encourages the students to take notes during their lecture. If lecturing is done in online class, then the learners may enter their doubts in the chat box which will be answered at the end of the meeting (online 
class).

It is most widely acceptable methodology, because the learners are more attentive and at the meanwhile, their doubts have been cleared which does not affect the other learners. It is totally different form the traditional class room methodology.

\section{Transformation During COVID-19}

COVID-19, a pandemic virus which affects nearly 212 countries and moreover it totally changes the life style of human beings. Due to this lock down situation, people are not able to move outside for any reasons. This pandemic condition not only changes the human life style, it also changes the traditional method of teaching and learning process.

This situation makes the entire educationalist as well as the professor to think of online class room preparation for the benefits of student's in order to provide uninterruptable education. This online classroom teaching will build the students to keep in touch with the subjects and make them to educate.

For this our recent technologies supports more, there are so many platforms to support free webinar, online class, providing assignments, uploading materials and short notes, quiz and so on. This methodology also helps the lecturer to verify the students' performance easily and accurately by providing different tools. Here, learners can also record the lectures and can listen to it later when it is needed for them. The learners need not to sit for a quite long time and it is not burden for them. They are able to open the material at any time and can learn on their comfort zone. Some of the basic tools are listed below to make the online class more effective:

i) Laptop.

ii) $\quad \mathrm{MIC}$

iii) Digital Tablet with pen (Mathematical and Drawing)

iv) Audio editing tools (for boosting audio levels)

v) Power Point Presentation (Preparing slides)

vi) Online class platforms (free websites)

The main advantage of using these tools is mostly open sourced material without paying a single rupee. It promotes self-learning and creates responsibility among the learners. It relieves stress, less pressure and intensity and can work at their convenience. They even learn the concepts and implement practically through their learning. They are being acquainted with transfer the file, updating technical concepts, incorporate video materials and assignments, preparing slides relevant to their technical area etc.

Transformation of learning process during COVID-19 is remarkable which develops strong self-discipline and easy accessible. This learning process makes much easier to focus on what is done and lays them in the right environment. It also makes them to learn different software's related to online course preparation. This develops a comfortable interaction between the instructor and the learner and communicates well digitally. The learner undergoes much easier to interact with the peers and also with the instructor. This digital online platform increase computer 
skills, develops technically through practical oriented and inculcates self-learning and creativity. It has more benefit than traditional teaching.

\section{Reference:}

[1] Atal Incubation Centre Pondicherry Engineering College Foundation, Webinar on How to Conduct Online Classes to Students, by Dr.R.Sundaramurthy on 3003-2020. 


\title{
Innovative and Creative Learning in Covid-19
}

\author{
Bazani Shaik ${ }^{1, *}$, G. Harinath Gowd ${ }^{2}$, B. Durga Prasad ${ }^{1}$ \\ ${ }^{1}$ Jawaharlal Nehru Technological University Anantapuramu, Andhra Pradesh. \\ ${ }^{2}$ Madanapalle Institute of Technology and Science, Andhra Pradesh. \\ "Email: bazanijntua@gmail.com
}

Innovative teaching and learning process is very useful contacting and sharing the data as useful manner in present Covid-19 pandemic situation. Teaching is a good challenge for all the faculty, industrial advisors, Research advisors, prime minister's, presidents all over the world. The present scenario teaches good lesson's for maintaining of social distance and awareness of cleaning and home quarantine. The innovative learning shows many solutions in useful manner to have healthy and safe. It shows flexible and suitable, Good solutions and helps us to manage, summaries, aggregate information. It is also useful for the search engines Google, yahoo, bing..etc. The innovative teaching is a manner of computational treatment of human language and Processing of speech, challenges. It has the translation process in between human contacts for the fundamental goal,deep understanding, languages are summarised with useful information in present creative and innovative world.

\section{Reference}

[1] Dr.G.Harinath gowd, Dr.B.Durga Prasad, BBC,NDTV,India today 


\title{
Different Ways COVID-19 Could Change How We Educate Future Generations
}

\author{
M. Prasad ${ }^{1}$, B. Jagadeesh ${ }^{2}$, A. V S M Ganesh ${ }^{3}$, G. L N V S Kumar ${ }^{3}$, N. \\ Lakshmi $^{3}$ \\ ${ }^{1}$ DU, Dilla, Ethiopia \\ ${ }^{2}$ Godavari Institute of Engineering and Technology, Rajamahendravaram, Andhra \\ Pradesh, India. \\ ${ }^{3}$ BVC Institute of Technology \& Sciences, Bhatlapalem, Andhra Pradesh, India. \\ *Email: ajita.sansita.m@gmail.com
}

In today, our educational institutions have most of the students coming from the generation $\mathrm{Z}$ which is has been developed with a fully globalized world. As of this actual universal epidemic, this generation may probably reflect the education of students who are at present 25 years old by facing the cancellation of exams, sports events and also graduations. The technology defines this generation in which the instantaneous communication and feedback prospect of Fear of Being Alone (FOBA) and Fear of Missing out (FOMO) are expressed. These are performed by the applications (apps) such as WhatsApp, Snap chat and Instant Messenger which includes the educators and parents to be reinforced by the today's remote learning.

The power of solving greatest challenges of the world in the main agenda of climate change and mental health with the collaborative work and mutual responsibility of isolate themselves at this situation to protect older people of the society is seen by this generation.

We are confident about the all educators like us that they all are wondered in what are required to prepare the students for their future in the middle of this COVID 19 disaster. According to the report of Dell Technologies, $85 \%$ of jobs will not yet been created for the Generation Z and Alpha in 2030. Also, according to present World Economic Forum report, $65 \%$ of elementary school children will now work in the jobs which are still not existed.

Crisis of this COVID 19 could change the world and global perspective. It can also teach us how the education should be changed so that we can prepare our young students in a better way for the future. These programs consist of as follows:

\section{Education People in an Interconnected World}

The way of interconnection between us over the globe has being shown in this epidemic of COVID-19 and there is no longer such an object as isolated problems and activities. This interrelation must be understood by the successful citizens in the upcoming 
decades and should found the way across restrictions to take advantage of their divergence for working together globally.

\section{Redefining the Role of the Educator}

For the intention of 21 st century education, the role of educators like a knowledge holder which were teach the knowledge to his students is not suitable for the long time. It is required to redefine the educator's role in the classroom and in the lecture stages, since students can access knowledge and can still gain knowledge of technical skills with their computers, tablets and cell phones by just doing some clicks on it. This may mean that the role of educators should help to facilitate the development of young people who are contributing as the members of society.

\section{Teaching the Life Skills Required for Future}

The flexible and adaptable skills which were proved as essential ones to navigate throughout this COVI 19 epidemic effectively are required to the young people for this ever-changing global environment. The communication, collaboration, creativity as well as empathy and emotional intelligence are some of the key skills required by the employers and they are be able to work on different demographic places with exploiting the power of the unity through effective teamwork for the future prospective.

\section{Technology Unlocking for the Education Delivery}

In order to make a distance learning content in all subject areas for the students, this COVID 19 epidemic forced educational institutions around the globe to abruptly exploit and use the available technological tools. Educators around the globe experience new opportunities to do things in a different and flexible way by means of potential benefits for students around the world in accessing education. These are new forms of teaching that have previously been largely overlooked, mainly in the 12th grade kindergarten

\section{Reference}

[1] https://reports.weforum.org/future-of-jobs-2016/chapter-1-the-future-of-jobsand-skills/

2.https://www.delltechnologies.com/content/dam/delltechnologies/assets/perspe ctives/2030/p df/SR1940_IFTFforDellTechnologies_HumanMachine_070517_readerhigh-res.pdf

[2] https://www.psychologytoday.com/us/blog/happy-singlehood/202001/the-fearbeing- alone-foba

[3] https://en.wikipedia.org/wiki/Fear_of_missing_out 


\title{
Recent Teaching Techniques During Covid'19 - an Overview
}

\author{
V. Sridevi ${ }^{1, *}$ \\ ${ }^{1}$ Department of Commerce, Sri Krishna Adithya College of Arts and Science, \\ Coimbatore. \\ *Email: shridharshana@gmail.com
}

Nowadays, everyone is suffering from the negative impact of the Coronavirus (COVID-19) pandemic worldwide. Online education is conducted in two ways. The first is through the use of recorded classes, which, when opened out to public, are referred to as Massive Open Online Course (MOOCs). There are many platforms created to enable online education in India. These are supported by the Ministry of Human Resource Development (MHRD), the National Council of Educational Research and Training (NCERT), and the department of technical education. There also are initiatives like e-PG Pathshala (e-content), SWAYAM (online courses for teachers), and NEAT (enhancing employability).

The second one is via live online classes conducted as webinars, or zoom sessions. Universities require high-speed internet and education delivery platforms or learning management systems, besides stable IT infrastructure and faculty members who are comfortable teaching online. Students also need high-speed internet and computers/mobiles to attend these sessions or watch pre-recorded classes. The teaching in all educational institutions has been shifted to distance learning through online platforms. Meetings, seminars, and conferences have been rescheduled to be held online through video conferencing software programs such as Zoom, Webinar, Google Meet. While many people are considering the implementation of new technology to education as an innovative step towards the development of smart online education, teaching online has some challenges for both professor and students. One of the most common challenges of distance learning is the lack of engagement between professor and student. This lack of motivation to learn online results from many factors.

For student's lack of engagement usually stems from long lectures, a plenitude of materials in one lecture and difficulty of subjects.

For professor's difficulty in teaching and lack of motivation results from the unfamiliarity of teaching online courses, not having the required digital skills for online teaching, lack of resources in some subjects and time management. To get students motivated to learn any subject, some techniques are required to be implemented to transform teaching online classical courses into fully engaging and interactive online courses.

Teachers can overcome the lack of motivation challenge in e-learning by 
following my three tips:

1. Online Meetings: Teachers can create weekly online meetings via many online video conferencing services such as ZOOM, Google Hangouts, and Skype. In each online meeting, teachers can discuss with students their concerns, questions, and suggestions to improve the class. This is very helpful in socializing with students which can make students feel motivated to continue learning the class topics.

2. Online Tutoring Sessions: This is similar to the first tip, but the difference is that in those sessions, teachers can only answer students' questions about the course assignments, projects, and exams. In addition, teachers can offer a review session the day before exams to discuss with students what they need to study and understand before going to exams. Tutoring sessions can make a great positive difference for their prep.

3. Virtual Office Hours \& Interactive Forums: Teachers can set up office hours virtually through online forums. They can start a topic in their forums, and set up a time each week. Students can ask the teacher about assignments and projects or can simply engage and discuss fun topics together. Students may also request make-ups for missed assignments or quizzes.

Hence, the students tend to successfully learn difficult topics in any subject if the professor can implement interactive teaching techniques in his/her teaching. A good preparation for the course from the teachers can contribute to the application of interactivity in any course topic so that students can be motivated to e-learn.

In conclusion, applying the above tips can successfully help all teachers transform the online teaching into interactive teaching that can get students motivated to learn subjects through online platforms during and post the COVID-19 world.

\section{References:}

[1] https://www.business-standard.com/article/education/education-in-the-time-ofcovid-19-how-institutions-and-students-are-coping-120043001575_1.html

[2] https://www.evmonews.com/post/e-learning-covid-19-world 


\title{
Kalam's India Vision 2020- Have We Reached the set Goals on Education System?
}

\author{
N Monica Madhuri ${ }^{1,}$,, G Blessy Christina ${ }^{2}$, C. Yosepu ${ }^{3}$, R Sam Sukumar ${ }^{4}$ \\ ${ }^{1}$ Department civil Engineering, Ellenki college of engineering and technology, \\ Hyderabad, India. \\ ${ }^{2}$ Department of ECE, Swarnandhra College of Engineering and Technology, West \\ Godavari, Andhra Pradesh, India. \\ ${ }^{3}$ Department of CSE, St Martins Engineering College, Hyderabad, India. \\ ${ }^{4}$ Panchayath Raj, Government of India, Mogalthuru, West Godavari District, \\ Andhra Pradesh, India. \\ *Email: smonicamadhuri@gmail.com
}

\section{Introduction:}

INDIA 2020- A Vision for the New Millennium book written by Dr APJ Abdul Kalam and Y S Rajan in his first chapter can India Become a Developed Country? he started with quote "All the brothers of the poor despise him, how much more do his friends go far from him! He pursues them with words, but they are gone. -Old Testament proverb 19:7". Really this is the state of mind of citizen of India on poverty and poor man. That is the reason After one of his talks delivered by Dr Kalam, a ten-year-old girl came up to him for his autograph. 'What is your ambition?' he asked her. 'I want to live in a developed India,' she replied without hesitation. So his book is dedicated to her and the millions of Indians who share her aspiration. But the question is as we entered into 2020 with lots of hopes and desires to enjoy in the fulfilled dream of INDIA 2020. But are we really fulfilled is a big question let us analyse the present status of INDIA-2020 looking with the eyes of Dr APJ Abdul kalam. Inspite of KALAM INDIA Vision 2020 the current globe is facing a desperate problem due to COVID-19, due to this all the countries get back to 20 years in development there is a much greater challenges are going to face through out the globe to address this problem. Therefore COVID-19: Creating a paradigm shift in India's Education System. For this to be a reality, an intense change in point of view is required in the outlook of strategy producers, specialists, understudies and exceptionally educationists. Personnel determination ought to step by step be connected to innovation invitingness and insight for innovation selection. Likewise, accreditation parameters, models need re-examination. Every one of these means will help reinforce the nation's computerized learning foundation over the long haul. Covid-19 has just quickened appropriation of innovations to convey instruction. 


\section{Kalam Vision is Here:}

The late former President Abdul Kalam has a unique identity among the people. He has many expectations of what India should look like and its appearance by 2020 . In the year 2000, the Vision-2020 document was prepared by Kalam with 500 experts from the Technology Information and Assessment Council (TIFIC) in the field of science and technology. Together with YS Rajan, he brought the book titled Why 2020: A Vision for the New Millennium. India's natural resources, human resources and competitiveness among Indians are predicted to make our country stand out against the powerful ones. India is expected to reach all developed countries by 2020 , with the expectation that by 2020, the country's all-encompassing development will be accompanied by education. If we want to create a corruption free society, we have to increase literacy. 'Call on young people to dream and realize them. Gross domestic product should be 11 per cent by 2020 if India is to reach its peak.

\section{Kalam Vision- Education System:}

The year 2000 was a fascinating year. There was so much excitement at the beginning of the new millennium, many of us imagining a technology-led future and a brave new world. The Millennium Bug is more than just a Y2K problem. At the same time, with the encouragement of the then President APJ Abdul Kalam, the Planning Commission came up with the Bharat Vision 2020 Omni Document. This Vision 2020 sets out what the country should look like after 20 years. Now, however, that time has come. Have we reached those goals now? Or not? The time has come to check. Have we achieved growth and growth without any challenges? India has reached its goals in any field. It is important to consider why the goals were not met. Have we failed to meet the goals of education now? Let's see how far we have succeeded. The cost of education has increased but the education sector has had mixed results. The number of educators has increased significantly. At the same time, the government has spent large sums of money on the mid-day meal scheme, Sarva Shiksha Abhiyan and the construction of buildings in rural areas. All India Survey 2018-19 Extensive Information on Higher Education from School. The number of students enrolling in colleges after elementary education has been very low. STs are still away from higher education. For example, Scheduled Tribes (STs) make up 8 percent of the population and only 5.5 percent of them go on to college education. The STs constitute $8.5 \%$ of the population. Only $2.3 \%$ of the teachers are from the ST. Legally they are unable to increase their representation despite reservations. That number has increased to 642 in 2011-12. The number of existing universities is 993. The National Knowledge Commission estimates that there will be 1500 universities by 2020 to educate the youth of the country. But to achieve that goal, another 500 universities will need to be set up. Government intervention is just that quality of education? Quality deficiency is higher in higher education. This seems to be the result of the government not intervening in institutions of higher education. It must be said that the government is not giving proper guidance to those 
educational institutions. Only 25 percent of young people aged 18-24 years are attending college and university. Over 10 million students receive degrees each year. It is noteworthy that 65 per cent of undergraduate students are studying. It is worrying that students gaining the degree do not have the right skills, knowledge and skills needed for employment. They only have some research skills. Teaching levels are not high in our universities, research quality is endless.

Due to COVID-19 the education system is accelerated to use new technologies to deliver the content to the students. For this to be a reality, an intense change in point of view is required in the outlook of strategy producers, specialists, understudies and exceptionally educationists. Personnel determination ought to step by step be connected to innovation invitingness and insight for innovation selection. Likewise, accreditation parameters, models need reexamination. Every one of these means will help reinforce the nation's computerized learning foundation over the long haul. Covid-19 has just quickened appropriation of innovations to convey instruction.

\section{Reference}

[1] A.P.J. Abdul Kalam and Y.S. Rajan, "INDIA 2020 A Vision for the New Millennium" PENGUIN BOOKS, 1998.

[2] http://planningcommission.nic.in/

[3] 3.https://www.who.int/blindness/partnerships/vision2020

[4] https://presidentofindia.nic.in/

[5] 5.https://en.wikipedia.org 


\title{
Teaching and Learning with Technology- E Learning Process
}

\author{
Gaurav Rajan ${ }^{1, *}$ \\ ${ }^{1}$ MMED, Indian Institute of Technology, Roorkee, Uttarakhand, India \\ "Email: rajan.gaurav67@gmail.com
}

As we know, COVID 19 is an infectious disease and people of most countries are facing pandemic conditions caused by coronavirus ${ }^{1 *}$. To avoid this situation, the world is looking for effective measures like lockdown, social distancing, self-isolation and quarantine etc. So that people is losing public relations with each other. But in this hour of trouble educational learning is one of the essential things that should not be stopped. So there is a big challenge to deliver all necessary information to the learners from the educators. It is very important to communicate and transfer knowledge with a sustainable goal among student, professor, educator and learner. Digitization process is a good option to convey knowledge of all kinds in all formats. So out of many innovative teaching and learning processes, the E-learning process plays a big role to create a connection between the teacher and learner in a lucid manner.

Through the E-learning process teacher can create a virtual classroom in which he can share lectures, contents, videos, assignments, quizzes etc. to the uncountable learners $^{2^{*}}$ at any desired time and also can take suggestions, doubts, feedback at the real-time. Through this innovative method, learners can easily access resources within their comfort zone. E-learning facility also ensures that learners who have missed classes can access it as per their convenience. It also reduces the heavy load of the physical classroom and provides comfortable study with breaks. Teachers can evaluate a learner's progress and performance individually with the weekly or monthly reports. Some important features of E-learning process are-

- $\quad$ Creative and Convenience
- $\quad$ Distance Education
- $\quad$ Flexible study timing
- $\quad$ Record and relearn
- $\quad$ Right content to right audience
- $\quad$ Mobile learning without space constraints
- $\quad$ Virtual class room and cloud spacing
- Smooth connection between teacher and learner


- Online training and certification

\section{How to access E-Learning:}

Learners have to $\log$ in from their convenience place with one of the accessible networks at given address or meeting details in order to access e-learning contents. Each individual has a right to interact with the host or educator during the session. There are many creative and technical methods available to make a connective bridge of e-learning between a motivational teacher and an enthusiastic learner-

- Through virtual reality classroom

- $\quad$ Third party private network

- $\quad$ Through email/websites/mobile apps

- Through video calling/conferencing apps

- $\quad$ Through Broadcasting podcast

- $\quad$ By using YouTube video sharing platform

So we can say that the E-learning process is one of the best alternative methods to provide teaching with smart learning at anytime, anywhere.

\section{References}

[1] https://www.who.int/emergencies/diseases/novel-coronavirus-2019

[2] Solc Marek, Legemza Jaroslav, Andrea Sutoova, Girmanova Lenka, "Experiences with utilizing e-learning in education process in university environment", Procedia - Social and Behavioral Sciences 46 (2012) 5201 - 5205 


\title{
A Perspective Study: Online Education/ Classes for Students to Aid During Covid-19 Pandemic
}

\author{
Vishwanath patil ${ }^{1, *}$, Pankaj jadhav ${ }^{1}$, Maheshkumar nippani ${ }^{1}$ \\ ${ }^{1}$ sharnbasva university, kalaburagi, Karnataka, India. \\ "Email: vishwanath.patil09@gmail.com
}

\section{Eternal Truth}

Allam Prabhu was a 12th century saint and vachanakara of Kannada language. His Vachana suits for present situation [1].

"Kaṇụu kaṇụudanellava koṇụu, aț̣ahāsadi mereva janake, kāṇada jīviyu bandu, tallaṇisuvudujagavunōḍā guheśvara" -allamaprabhudēva.

\section{Point of View}

The whole world now is in self-isolation, as the pandemic COVID-19 has put the whole world on hold and we are waiting for release from temporary confinement during this period the teaching and learning has become difficult, so to overcome this and to make it beneficial to the students, our institution has started online teaching and learning process by means of different learning platforms [2].

During this period rendering online education and classes makes more sense, to boost the student's career during this uncertainty, online learning gives the control the anxiety of the students and parents.

The current situation has forced all educational institutions to transition from classroom teaching to online classes; all teaching faculties have to enhance their teaching through digital interventions [3].

Due to this pandemic condition, as parents are getting worried about the education of their ward/ child, we teaching faculty are coming up with creative ideas, experiments with practical demonstrations to enhance the student's level of understanding the subject depth.

Before the next class, the student is given a task or home assignment to be well engaged in the home to ensure continued process of learning.

The online education mode of learning brings with it some unique advantages or benefits such as flexibility, rich learning experience and quality content. For most of the teachers and educators in India who are accustomed to the traditional in-person, classroom style of teaching, this up skilling to taking online classes will call for some preparation.

Some basic points that could be helpful to teacher/ Educators while taking online classes.

- Set points for discussion at the beginning of the session of the previous 
topic.

- Conduct topic wise test of each session/class.

- Classes/ session should be minimum of 45 minutes to have the students their maximum concentration without any distractions.

- To make classes more interesting, demonstrations can be given.

- If classes/ sessions are more than 45 minutes breaks can be given.

- Encourage interaction and communication by online class.

- Students have a plot form where they can connect with their teachers

- Students can have peer group discussions amongst them with help of internet apps through chatting, video group calling.

Online education experiment shows good momentum on account of the pandemic, it could also be a good opportunity for teachers to reflect on the learning from this situation. These online platforms will be more productive.

\section{Conclusion}

- This process ensures continued teaching process to the students during this period.

- Students are definitely beneficial by this online teaching/ webinars.

- All the faculties become well worse with online teaching as well as it familiarizes the students with the online classes.

- By this we would like to say that "nothing is impossible"

- As we are enjoying the benefits of telecommunication, tele therapy in this era.

- Yes, we are likely to share the knowledge through this online process.

- We can not only share the knowledge by social distancing we are helping the country fight against COVID-19

\section{Reference}

[1] ShivaPrakash,H.S. (1997)."Kannada". In Ayyappapanicker (ed.). Medieval IndianLiterature:AnAnthology.Sahitya Akademi. ISBN 81-260-0365-0.

[2] https://www.who.int/news room/detail/10-03-2020-covid-19-ifrc-unicef-andwho-issue-guidance-to-protect-children-and-support-safe-school-operations

[3] WHO. Novel Coronavirus (2019-nCov)SituationReport22[EB/OL].(2020-0211)[2020-03-15].https://www.who.int/emergencies/diseases/novel-coronavirus2019/situation-reports/ 


\title{
ICT Tools for Effective Learning and Better Placements
}

\author{
Srinivas Adapa ${ }^{1, *}$, G. Lakshmi Durga ${ }^{1}$, Y. Lavanya ${ }^{1}$, B. Kiran ${ }^{1}$, P. Vijaya \\ Rekha ${ }^{1}$ \\ ${ }^{1}$ Coastal Institute of Technology and Management, Narapam, Veerabhadrapuram \\ (P), Kothavalasa M, Vizianagaram, Andhra Pradesh, India \\ "Email: a.srinivas@citm.ac.in
}

\begin{abstract}
Information and Communications Technology is a very useful tool in making the Teaching process very interactive for better learning of students. This article briefly discusses different ICT tools that students can use for better career placements.
\end{abstract}

\section{Introduction}

ICT plays a major role in terms of teaching, learning and understanding of any concept however difficult it is. Information Technology (IT), as defined by the Smart Computing Dictionary, is "A general term used to describe any technology that helps to produce, manipulate, store, communicate, or disseminate information. IT refers to the most expensive, complex computers, with devices usually dealing with electronic data in binary format. However, these IT machines are not able to communicate with one another."

All around, instructive frameworks are embracing new innovations to incorporate ICT in the educating and learning process, to get ready understudies with the information and abilities they need in their topic. Thusly the encouraging calling is developing from instructor focused to understudy focused learning situations. There are so many ICT tools however in this article we will focus on the most important 10 tools for students. Most of the tools mentioned in this article are available free of cost.We will see some of the ICT tools that are beneficial to students for their effective learning and better career.

1. Google: Students learn many things and before writing the exams itself they forget most of the things. While attending any competitive exams and interviews they will tend to forget. In this situation, Mind Maps will play a major role in memorizing the things and this tool becomes handy in preparing the mind maps for any topics at ease and you can store them in your google drive or download them in several file formats like jpg, png, pdf, ...etc. The clear way to share complex information. Coggle is a 
collaborative mind-mapping tool that helps you make sense of complex things. To create your own mind maps, visit - https://coggle.it/

2. PDF Drive: Sometimes students can't afford to buy their subject textbooks and if we buy technology related textbooks also it becomes obsolete within several months and the textbook is no longer useful. PDF Drive is your search engine for PDF files. As of today we have 80,641,739 eBooks for you to download for free. No annoying ads, no download limits, enjoy it and don't forget to bookmark and share the love! To download your ebook visit - https://www.pdfdrive.com/

3. GitHub: GitHub Education helps students, teachers, and schools access the tools and events they need to shape the next generation of software development. This is a free platform for students who want to enter into a software development career. For signup visit https://education.github.com/

4. TED-Ed: TED-Ed is TED's youth and education initiative. TED-Ed's mission is to spark and celebrate the ideas of teachers and students around the world. The students can sign up with TED-Ed with their interested topics and TED will send those related domain area animated videos/lessons for learning. This platform is useful for students, parents and teachers for learning. To learn more visit - https://ed.ted.com/

5. Hunter: Hunter lets you discover email addresses like a flash and interface with the individuals that issue for your business. If the student wants to find any company HR or any personal details then this tool is going to help a lot. To access this tool here is the URL - https://hunter.io/

6. Loom: These days the recruiters are preferring short video profiles than several lengthy pages of text resumes. Say it with Video - Loom is the most effective way to get your message across, no matter where you work. To use this tool, you can visit - https://www.loom.com/

7. GMass: GMass allows you to easily schedule emails, send out mass emails and mail merge campaigns and more with Gmail! This is mostly used as a marketing software which is available free with google chrome browser extension. We have several recruiters email ids with us and without including them in bcc (blind carbon copy) we can send all of them at once without knowing each other in a professionally customized fashion using GMass tools. To know more about this tool visit - https://www.gmass.co/

8. Canva: Canva is a visual communication platform that permits clients to make online life illustrations, resumes, introductions, banners, posters and other visual substance. It is accessible on web and portable, and incorporates a great many pictures, text styles, formats and delineations. Using this tool you can prepare a creative resume for applying to various companies for recruitment. To learn about this tool visit https://www.canva.com/

9. Pramp: Join thousands of professionals practicing live mock interviews \& interview questions online, with peers, for free. They help students prepare 
interview questions \& land their dream tech job. To practice mock interviews visit - https://www.pramp.com/\#/

10. Jobscan: We generally tend to prepare one standard resume and apply for different job positions with several companies. As our resume content doesn't match with job requirements or job description so it is very less chance for us to get an initial round of Interview. To avoid such embarrassing situations this tool Jobscan will help, this will scan your resume and the job description. After scan it will suggest where we need to do modifications in our resume to meet the job requirement. Jobscan is built from algorithms used in top Applicant Tracking Systems (ATS). Optimize your resume keywords and get more interviews. To scan your resume visit - https://www.jobscan.co/

\section{Conclusion}

Nowadays students are lacking in communication skills like speaking, net etiquette, resume writing skills and technological skills to face any job oriented interviews. The above mentioned tools will be of great help for students to learn , memorize, qualify and get better placements.

\section{References}

[1] Integrating ICT in Teaching and Learning, https://www.ukessays.com/essays/education/integrating-ict-in-the-teaching-andlearning-process-education-essay.php , published on: 13-12-2017; accessed on: 05-05-2020 


\title{
10
}

\section{Collaborative Teaching by Identifying Students Learning Style}

\author{
Srinivas Adapa ${ }^{1,}$, N. Seshu Kumar ${ }^{1}$, Netaji Gandi ${ }^{2}$, Madhu Mugili ${ }^{3}$ \\ ${ }^{1}$ Coastal Institute of Technology and Management, Narapam, Veerabhadrapuram \\ (P), Kothavalasa M, Vizianagaram, Andhra Pradesh, India. \\ ${ }^{2}$ MRCL, Vizianagaram Dist, Andhra Pradesh, India. \\ ${ }^{3}$ Tirumala Engineering College, Hyderabad, India. \\ *Email: a.srinivas@citm.ac.in
}

\begin{abstract}
:
We are Teaching, however Are They Learning? - This is the primary essential inquiry each instructor/teacher/mentor ought to ask themselves in light of the fact that there is a gigantic hole among educating and realizing which brought about poor learning by understudies. If the faculty/teachers can adjust their teaching pattern based on the student learning style, then surely we can increase the subject interest among students. The learning styles concept has much potential with underprepared students. Collaboration can be implemented across all instructional levels and subject areas. In this article we can integrate the learning style of a student and collaborative teaching to make all the students understand what we are teaching irrespective of the learning capability of the student!
\end{abstract}

\section{Introduction}

"Collaborative teaching, sometimes called cooperative teaching or team teaching, involves educators working in tandem to lead, instruct and mentor groups of students."[1] Learning styles are different methodologies or methods for learning. They include instructing techniques, exceptional to every person that is ventured to permit him/her to adapt best. The vast majority incline toward a recognizable strategy for communicating with, taking in, and handling upgrades or data. To be effective, the strength of joint exertion requires wise idea regarding educators. Time must be put something aside for making practices and picking fitting learning approaches to manage use with express' understudies or gatherings.

Teaching Collaborations Types [1]:

There are wide assortments of cooperative/collaborative training styles and many are utilized reciprocally by group instructors. Particular models include the following [1]:

- Lead, Observe, Assist

- Educate and Reteach 
- Simultaneous Teaching

- Instructional Stations

- Supplemental Teaching

- Co-teaching Rotation

As a teacher we can adopt any one of the above mentioned Collaborative techniques depending on the subject topic, strength of the classroom and learning styles of the class which we are going to discuss in the next section of this article.

\section{VARK Learning Styles:}

The learning style suggestions are not exhaustive but are meant to provide instrumental alternatives for teachers in real classrooms. These strategies were developed by instructions as representative of things teachers can do to maximize effective teaching. If you want to know your learning style, please attempt the questionnaire available at https://vark-learn.com/the-vark-questionnaire/.

1. Visual (V): Somebody with a Visual learning style has an inclination for seen or watched things, including pictures, outlines, coordinators, illustrations, displaying, blackboard, stick exercises, instructional TV, nonverbal communication, diagramming, exhibits, shows, freebees, films, flipgraph, and so on.

2. These people will use articulations, for instance, 'show me', 'we should see that' and will be best prepared to play out another task in the wake of scrutinizing the bearings or viewing someone else do it first. These are the people who will work from records and composed headings and rules.

3. Auditory / Aural (A) : Somebody with an Auditory learning style has an inclination for the exchange of data through tuning in: to the verbally expressed word, of self or others, of sounds and commotions. Recommended procedures for Auditory (Hearing) is tape and read, tune in and look at, address, singing back, talk and tune in, blindfold, sound tape, Socratic addressing, agreeable adapting, orally condense, thoroughly analyze, bunch work.

4. These people will use articulations, for instance, 'let me think', 'we should talk it over' and will be best prepared to play out another task in the wake of checking out bearings from an expert. These are the people who are happy being given spoken headings through telephone, and can review all of the words to tunes that they hear!

5. Read / write (R): This preference is for information appeared as words. As anybody would expect, various educators and understudies have a strong tendency for this mode. Having the choice to make well and read by and large are properties searched for by organizations of graduates. This tendency underlines text-based data and yield - examining and writing in the aggregate of its structures yet especially manuals, reports, works and assignments. People who incline toward this approach are routinely subject to PowerPoint, the Internet, records, diaries, word references, thesauri, 
references and words, words, words... Note that most PowerPoint presentations and the Internet, GOOGLE and Wikipedia are fundamentally fit to those with this inclination.

6. Kinesthetic / Haptic (Tactile) (K) : Somebody with a Kinesthetic learning style has an inclination for physical experience - contacting, feeling, holding, doing, down to earth hands-on encounters. Recommended methodologies for Kinesthetic individuals are Skits, introductions, board work, Projects, Labs, Demonstrations, Investigations, Simulations, Educational Games, bunch work,...etc.

7. These people will use articulations, for instance, 'let me handle', 'how might you feel?' and will be best prepared to play out another task by not hesitating to try it out, learning as they go. These are the people who like to break down, hands-on, and never look at the rules first!

\section{Conclusion}

Collaboration is an awesome instructing tool. Educators get the opportunity to study and separate direction for understudies even more expeditiously and they can take in new instructional strategies from each another to broaden their teaching assessment. Individuals ordinarily have a principle favored learning style, yet this will be a piece of a mix of every one of the three. A few people have a very solid inclination; other individuals have an all the more even blend of two or less regularly, three styles. For instance: male formative understudies who have a haptic/Kinesthetic direction ought to likewise be approached to listen cautiously, as when the guidelines are given. Once we find the students' learning style then we can form the teams based on the VARK and do the collaborative teaching for students better learning.

\section{Reference}

[1] WhatisCollaborative Teaching?, https://www.topeducationdegrees.org/faq/whatis-collaborative-teaching/, Accessed on 06-05-2020.

[2] Mr. Srinivas Adapa; Mr. Netaji Gandi; Mrs. Alekya Vechalapu; Ms. G.Lakshmi Durga, Learning Style Recommender System using VAK Technique and Machine Learning, Conference: INDIA 2019, published on: December 2019.

[3] http://knowledge.wharton.upenn.edu/article/the-objective-of-education-islearning-not-teaching/, Published:August 202008 , Accessed: 05-05-2020.

[4] Srinivas et al, "Recognizing Smart People with NLP Techniques using AI Expert System”, Deepam Publication's, International Journal of Research in Engineering, Science and Technologies (IJRESTs), Vol.:03, Issue No.:01, May 2017, Pg. 14-17.

[5] The VAK Learning Style, Source: https://www.southwesterncc.edu/sites/default/files/VAK_Learning_Styles.pdf

[6] VARK version 8.01 questionnaire, Source: https://vark-learn.com/the-varkquestionnaire/, Accessed: 05-05-2020, 


\title{
11
}

\section{Trending Teaching and Learning Mechanisms in 21st Century}

\author{
P.M. Ebin ${ }^{1, *}$, R. Kavitha Nair ${ }^{2}$ \\ ${ }^{1}$ IES College of Engineering, Thrissur, \\ ${ }^{2}$ Mangalam College of Engineering, Kottayam \\ *Email: pmebin195@gmail.com
}

\begin{abstract}
Learning is a process by which a person acquires knowledge and skill through study, been taught or by experience. Learning has wide flexibility to adapt to any situations such that one who craves for knowledge could acquire it through many means. Now our world is facing with such a pandemic disaster, so many have to be self-isolated and nothing other than imprisonment inside four walls. But this situation is a chance to enhance our skillset within our isolation so that a wide set of online skill improvement programmes have been initiated, so many could utilize it in a fruitful way. Dedicating some of our quarantine time to improve self-education makes good sense. Now we can see many people are in an urge to enroll many online learning platforms which focuses on wide areas like technology, arts, humanities, personal development. So we would like to open some of good platforms you could use for e-learning purpose.
\end{abstract}

\section{Course Content}

Courses may vary based on the area, though most of them follow a same basic model. Always choose the courses that are delivered by the experts in respective fields. The courses may be of varying duration starting from days and extend to months. To understand your improvement, attempt online regular tests and quiz. Some of the courses may provide you up with a completion certificate of the course at the end.

\section{The Worth of a Course}

Most of the people look for e-courses that are delivered by reputable speakers, but always give an eye to the review of other learners too, that would help you to make a final decision. Always remember that the attempt to such e-courses is for your personal development as well to get recognition from your current or to be employers. The course level that select must of right difficulty and should be not selected based on your comfort zone. 


\section{Life After Your Course}

E-learning platforms give you a base of your skill. If you are still hooked to it, you may take advance courses and even graduate or post graduate to that particular area. The hunt for new, innovative skillset or discipline is the best way to be out of the frustrations you face from the self-isolation that make you to hang out with many new faces and get a transformation from this period to the time of selfdiscovery and enlighten.

\section{Innovative Teaching Mechanisms}

Teaching is a process which helps the students to acquire knowledge, improve ability and enhance righteousness. The best way of innovative teaching during isolation is through e-platforms. An instructor should be a facilitator. The instructor should fill the gap between the right content and where the students' knowledge stands. The effort of teaching mechanism must enhance the knowledge, attitude of learners and their skillset. The strategies for learning are framed by teachers and these are being learned by the students. The strategies' must mainly focus on the student's development and should be framed for each and every student and no discrepancies in that. The effect of teaching mechanism can be analysed based on questionnaire prepared based on the course. The level of questionnaire must follow different taxonomy's so that it could be used to analyse low order thinking skills to high order thinking skills.

Several innovative activities could be initiated to engage the learners during this lock down time. This time can be used for constructive teaching where assignments and activities should be delivered through e-platforms and be monitored by the teachers. Several technologies are adapted for this like Zoom classes, Google Meet, Google-classrooms etc are via which personalized attention can be given to the learners. It's the era of technology and parents should consider and offer their wards with better opportunities that helps them to explore to a new technical world. Many apps have waved their entry which contributes facilities for sharing materials, tutorials and also enable online discussion as of in a class. If these technologies found to be useful, it could be adopted in future for further learning purposes.

Flipped class room can be considered as a special kind of Active Learning in which students can participate actively in the area. In regular class room the instructors give lectures first, then home work. In Flipped class room first lecturing from the home (basic understanding of the concept) using video lectures, materials from internet etc and homework at school.

Experiential Learning project the Quotes, "Involve me, then I Learn". The biggest challenge in the 21 st century teaching is whether the students learn what the teacher is teaching. So be a facilitator instead of a simple teacher. Appropriate usage of teaching pedagogy influences students. Different styles of teaching learning process help the students to achieve their objectives. 


\section{STUDENT}
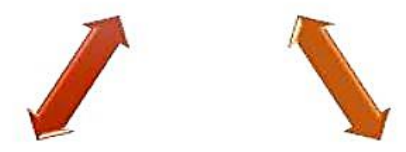

\section{FACILITATOR}

\section{CONTENT}

Fig 1. Changing the role of a teacher to a Facilitator in $21^{\text {st }}$ Century Teaching

\section{Reference}

[1] https://www.intechopen.com/books/new-pedagogical-challenges-in-the-21stcentury-contributions-of-research-in-education/pedagogy-of-the-twenty-firstcentury-innovative-teaching-methods

[2] https://www.researchgate.net/publication/325087944_Innovative_methods_of_T eaching_and_Learning

[3] https://www.ripublication.com/ijbamspl17/ijbamv7n1spl_14.pdf 


\title{
12
}

\section{Innovative Teaching Learning Methods in Technical Courses During COVID Lockdown}

\author{
Abhijeeth Nagaraj ${ }^{1, *}$, Nagaraj Sitaram ${ }^{2}$, N Karthik ${ }^{1}$ \\ ${ }^{1}$ Department of Mechanical Engineering, Faculty of Engineering and Technology, \\ Jain (Deemed-to-Be-University), Bangalore. \\ ${ }^{2}$ Department of Civil Engineering, East Point College of Engineering and \\ Technology, Bangalore. \\ *Email: n.abhijeet@jainuniversity.ac.in
}

COVID Lockdown has been a challenging time especially for teachers, as the method of teaching commonly is an interactive process. Education has been one of the fields that have been majorly affected by the COVID lockdown. Since education is an art of teaching by inculcating curiosity among the students and participants. As Arnold Edinborough rightly highlights in his quote "Curiosity is the very basis of education, and if you tell me that curiosity killed the cat, I say only the cat died nobly."

But with the inability of being present among the students to do so, it is a challenge for any teacher to hold the class together and teach them effectively. However, the spirit of curiosity can be an effective method to ensure the learning process among the students [1]. This habit has not been new, during school days students were asked to perform simple experiments to demonstrate the concept. In technical education in online mode, this method can provide an interest to understand and apply the concepts being taught about.

A few ideas of innovative teaching methods that can be employed in engineering online classrooms are explained. The innovative learning need not be a technology-based method but a method which enables an exploration-based learning. These are a few of many methods, and every teacher can try new methods to teach and make the class more interesting. The teachers should formulate the teams using techniques like Conflict instrument of Thomas Kilman, VARK analysis and Myers Briggs (MBTI)

The objective of the methods is to make the student understand the basic principles over a theoretical definition. The approach involves three fundamental parts, one is to explain the basic concept, second inculcating a need to explore the answers and third to justify their view over constructive criticism.

Critical analysis: The innovative method is to provide the team of students with real situations using suitable visual aids and details where the improvement is to be suggested using the concepts of the course. This involves the teams to understand a system, and evaluate it. Based on which an improvement is to be suggested. The team must present a justified reason for the identified limitation, and provide an 
innovative solution to the problem. The team should show the justifications to their solution. The activity is aimed at improving the team work, lifelong learning, creativity and critical analysis.

Experimental abilities: Experiment is one of the important aspects of engineering as they are the key to explaining concepts in engineering. In this method, the teacher should provide the task to each team for conducting an experimental demonstration of the concept. The team should be able to justify their experimental observation against the theoretical expectations and present a valid reason for any variations. The activity allows student to explore and understand the physical meaning of the concept and limitations in the theory.

Webinars, e-learning and visual aids: The teacher can expose the students to latest trends in the field using Webinars and video calls with industrial and subject experts from time to time. This provides a different view to the students which can be helpful in keeping them up-to-date about the current trend in research and industry. This can inspire innovative ideas, career guidance and collaborative projects among the students.

The e-learning platform accommodates conducting classes for students by on web or by providing recorded videos and additional study material for the student. This easy access to the materials among students provides the necessary support during learning. The teachers can also conduct online tutorials, discussions and quizzes for students using web platforms.

Visual aids for teaching are now becoming essential in teaching. This provides an easy understanding among students by providing necessary visualisation to understand complex concepts and parameters involved in it. The visual aid can be YouTube links, Java Applets, or Animations.

An effective teaching-learning process is essential for educational system, and any educational method will be as effective as the teacher who is a part of it. As Dr. APJ Abdul Kalam once quoted "Teachers are the backbone of any country, the pillar upon which all aspirations are converted into realities". Through the means of innovative teaching, let us help build aspiring young minds to achieve and transform their ideas to reality.

\section{Reference}

[1] Shenaar-Golan, V. and Gutman, C., 2013. Curiosity and the cat: Teaching strategies that foster curiosity. Social work with groups, 36(4), pp.349-359. 


\title{
13 \\ Scaling Online Teaching and Learning to Best Conventional Mode
}

\author{
Sripathi Vijaya Sailaja ${ }^{1}$, Addepalli Mallinadh Kashyap ${ }^{2,}$, Sivangi \\ Suryanarayana Raju ${ }^{3}$ \\ ${ }^{1}$ Department of Electrical \& Electronics Engineering, GIET Engineering College, \\ Rajahmundry \\ ${ }^{2}$ Department of Civil Engineering, GIET Engineering College, Rajahmundry \\ ${ }^{3}$ GIET Engineering College, Rajahmundry. \\ *Email: mallinadhkashyap@gmail.com
}

The impact of COVID 19 pandemic outbreak given a huge question to the entire globe towards its sustainment in several aspects startingat human health. Global economy come down to greater level in view of huge impact on the industry and other related sectors. Education sector is not an exception in this regard facing both direct and indirect impacts on the stake holders, viz., students, parents, academic fraternity. The entire educational industry is affectedas sudden forced closure with a prior precautionary measure as a part of implementation of nonexpansion activities of corona virus. In keeping view of the un predicted severity, big challenges are still ahead. As the situation is uncertain and in keep in view of compensation to the forced loss to existing student fraternity, educational institutions started implementation of online teaching learning process, instead of direct and conventional teaching activities with an intention to avoid absolute physical contact where one to one personal interaction between the teachers and the learners is maximum than any other teaching and learning methodologies. Though the online learning is not a new version and exists since several years, majority portion is confined to special learning aspects rather than the conventional mode of teaching learning processes in particular in India. Though this alternative immediate adoption for best compensation to the existing loss, there are several challenges in effective dissemination of the knowledge, one among them is the full-fledged engagement by the learners as the online teaching \& learning process witnessed lower extent in many cases in particular slow learners. In these constraints, effective attempts are more required to maximize the learner's engagement. As a part of our efforts to our efforts, we developed a typical strategy and deployed in the online process of teaching \& learning with game play approach that the leaners are well engaged actively throughout the session. Different learning management systems are available both in free and paid versions to cater the academic needs to a bets extent.

Gamified online teaching \& learning process is one of the best concepts in augmenting the real engagement of the students. As a part of verification of our concept, two sessions were engaged in parallel with the same concept of teaching 
one with gamification and other in normal mode with equipotent teachers. The sessions were reversed on the next day with the same group of teachers as presenters of the content. The results proven that the mode of online teaching with the inclusion of gaming mechanism as a special practice proven better effective in engaging the learners to a better extent as we generally observe in high trivial conventional mode of teaching. When compared to the online teaching without gaming mechanisms. The typical results are shown in Table 1(a) \& 1(b) for the identified cases of study for 6 days continuously in which the first attempt conducted by implementing the normal online instructional mode and the second attempt is with the inclusion of gamified online class mode

Table 1(a): Results identified for the present case study for III year B. Tech Civil Students

\begin{tabular}{|c|c|c|c|c|c|c|c|}
\hline $\begin{array}{l}\text { Details. } \\
\text { of } \\
\text { Sessions }\end{array}$ & $\begin{array}{l}\text { Name of } \\
\text { the Opted } \\
\text { Subject }\end{array}$ & $\begin{array}{l}\text { Total } \\
\text { No. } \\
\text { of } \\
\text { Stude } \\
\text { nts in } \\
\text { Class }\end{array}$ & $\begin{array}{l}\text { No. of } \\
\text { Student } \\
\mathrm{s} \\
\text { Attende } \\
\mathrm{d} \quad \text { for } \\
\text { normal } \\
\text { On-line } \\
\text { Class }\end{array}$ & $\begin{array}{l}\text { No.of } \\
\text { student } \\
\mathrm{s} \\
\text { retaine } \\
\mathrm{d} \text { for } \\
\text { total } \\
\text { Duratio } \\
\mathrm{n} \text { of } \\
\text { Class }\end{array}$ & $\begin{array}{l}\text { No.of } \\
\text { student } \\
\mathrm{s} \\
\text { retaine } \\
\mathrm{d} \text { for } \\
\text { total } \\
\text { Duratio } \\
\mathrm{n} \text { of } \\
\text { Class }\end{array}$ & $\begin{array}{l}\text { No. of } \\
\text { students } \\
\text { attended } \\
\text { for online } \\
\text { mode with } \\
\text { gamificati } \\
\text { on }\end{array}$ & $\begin{array}{l}\text { No. of } \\
\text { Students } \\
\text { Retained } \\
\text { for Total } \\
\text { Duration } \\
\text { of Class \% } \\
\text { increase in } \\
\text { efficacy in } \\
\text { gamificati } \\
\text { on online } \\
\text { mode } \\
\text { Against } \\
\text { normal } \\
\text { online } \\
\text { class }\end{array}$ \\
\hline $\begin{array}{l}\text { Session } \\
1\end{array}$ & $\begin{array}{l}\text { Concrete } \\
\text { Technology }\end{array}$ & 40 & 32 & 28 & 34 & 34 & $15.00 \%$ \\
\hline $\begin{array}{l}\text { Session } \\
2\end{array}$ & $\begin{array}{l}\text { Concrete } \\
\text { Technology }\end{array}$ & 40 & 34 & 29 & 36 & 35 & $15.00 \%$ \\
\hline $\begin{array}{l}\text { Session } \\
3\end{array}$ & $\begin{array}{l}\text { Concrete } \\
\text { Technology }\end{array}$ & 40 & 33 & 32 & 35 & 35 & $7.50 \%$ \\
\hline $\begin{array}{l}\text { Session } \\
4\end{array}$ & $\begin{array}{l}\text { Concrete } \\
\text { Technology }\end{array}$ & 40 & 35 & 34 & 36 & 36 & $5.00 \%$ \\
\hline $\begin{array}{l}\text { Session } \\
5\end{array}$ & $\begin{array}{l}\text { Concrete } \\
\text { Technology }\end{array}$ & 40 & 35 & 32 & 37 & 37 & $12.5 \%$ \\
\hline $\begin{array}{l}\text { Session } \\
6\end{array}$ & $\begin{array}{l}\text { Concrete } \\
\text { Technology }\end{array}$ & 40 & 35 & 33 & 37 & 36 & $7.50 \%$ \\
\hline
\end{tabular}


Table 1(b): Results identified for the present case study I Year ECE students

\begin{tabular}{|c|c|c|c|c|c|c|c|}
\hline $\begin{array}{l}\text { Details. } \\
\text { of } \\
\text { Session } \\
\text { s }\end{array}$ & $\begin{array}{l}\text { Name } \\
\text { of the } \\
\text { Opted } \\
\text { Subject }\end{array}$ & $\begin{array}{l}\text { Total } \\
\text { No. of } \\
\text { Student } \\
\mathrm{s} \text { in } \\
\text { Class }\end{array}$ & $\begin{array}{l}\text { No. of } \\
\text { Students } \\
\text { Attende } \\
\text { d for } \\
\text { normal } \\
\text { On-line } \\
\text { Class }\end{array}$ & $\begin{array}{l}\text { No. of } \\
\text { students } \\
\text { retained } \\
\text { for total } \\
\text { Duratio } \\
n \quad \text { of } \\
\text { Class }\end{array}$ & $\begin{array}{l}\text { No. of } \\
\text { students } \\
\text { retained } \\
\text { for total } \\
\text { Duratio } \\
n \quad \text { of } \\
\text { Class }\end{array}$ & $\begin{array}{l}\text { No. of } \\
\text { students } \\
\text { attended } \\
\text { for online } \\
\text { mode with } \\
\text { gamificatio } \\
n\end{array}$ & $\begin{array}{l}\text { No. of } \\
\text { Students } \\
\text { Retained } \\
\text { for Total } \\
\text { Duration of } \\
\text { Class \% } \\
\text { increase in } \\
\text { efficacy in } \\
\text { gamificatio } \\
\mathrm{n} \quad \text { online } \\
\text { mode } \\
\text { Against } \\
\text { normal } \\
\text { online class }\end{array}$ \\
\hline $\begin{array}{l}\text { Session } \\
1\end{array}$ & $\begin{array}{l}\text { Networ } \\
\mathrm{k} \\
\text { Analysi } \\
\mathrm{s}\end{array}$ & 60 & 54 & 48 & 56 & 56 & $13.6 .00 \%$ \\
\hline $\begin{array}{l}\text { Session } \\
2\end{array}$ & $\begin{array}{l}\text { Networ } \\
\text { k } \\
\text { Analysi } \\
\text { s }\end{array}$ & 60 & 54 & 47 & 36 & 35 & $15.00 \%$ \\
\hline $\begin{array}{l}\text { Session } \\
3\end{array}$ & $\begin{array}{l}\text { Networ } \\
\mathrm{k} \\
\text { Analysi } \\
\mathrm{s}\end{array}$ & 60 & 56 & 48 & 35 & 35 & $7.50 \%$ \\
\hline $\begin{array}{l}\text { Session } \\
4\end{array}$ & $\begin{array}{l}\text { Networ } \\
\mathrm{k} \\
\text { Analysi } \\
\mathrm{s}\end{array}$ & 60 & 56 & 47 & 36 & 36 & $5.00 \%$ \\
\hline $\begin{array}{l}\text { Session } \\
5\end{array}$ & $\begin{array}{l}\text { Networ } \\
\mathrm{k} \\
\text { Analysi } \\
\mathrm{s}\end{array}$ & 60 & 56 & 45 & 37 & 37 & $12.5 \%$ \\
\hline $\begin{array}{l}\text { Session } \\
6\end{array}$ & $\begin{array}{l}\text { Networ } \\
\mathrm{k} \\
\text { Analysi } \\
\mathrm{s}\end{array}$ & 60 & 58 & 46 & 37 & 36 & $7.50 \%$ \\
\hline
\end{tabular}

From the above results, the well identified secret behind this full-length engagement is the best motivation to the teachers and in particular the learners, who participated with lot of enthusiasm. Since, ancient days well motivated traditional teaching learning is under effective implementation in India where, the teachers and 
the learners getting used to conventional system of teaching and learning. Globalization forced the educational industry to adopt the utilization of online learning platforms with day by day substantial increase in India. However, the implementation is now become highly inevitable in view of the present unforeseen situations and it is likely to continue even in future as an adoptive change in educational sector.

At the keen observation of challenges in the adoption of the online teaching learning process, eventhough there is a virtual face to face interaction between the teachers and learners, the leaners found inactive at times due to lack of effective supervision tactics. In the above lines, in the current study, the gamification strategy is designed and implemented to accelerate the engagement of the learners in entire duration of the session. Further, the effective implementation of e gamified approach also improves the cognitive levels of the learners apart from learning engagement and conceptual learning.

\section{Experimentation:}

This context is the clear description of our case studies with the well specified tool kahoot, in quick implementation of actual games in online based teaching - learning sessions which proven motivated engagement of the learners.

In the present case study as explained, a well-known gaming tool, kahoot is deployed with necessary prior practice. The entire session for online lecture delivery was scheduled for 60 minutes. As a part of pre learning experience sharing, a questionnaire with the relevant content for a span of 10 minutes was designed and released online for learners to complete the questioner. Soon after completion of the specified time, a 30 minutes' class was taken place. Then after effective delivery of content, the learners were asked to explain their submissions of the questioner via login into kahoot into the application with the use of customized unique password. The major advantage with this application found that it gives result in the regard of topper of the session for question to question in which the topper name cannot be judged until the last question was answered by which the learners in particular slow learners feel sportive spirit in their online learning experience and engage in the online classes effectively with total learner centered approach.

\section{Conclusion:}

This paper is the clear explanatory evidence of augmentation of student engagement in online teaching learning process through gamification approach to make the online teaching- learning process a best as in the case of conventional mode of teaching learning approach. The revealed experiences can be effectively implemented to enhance the students learning. Therefore, we conclude that the implementation of this application increased the motivation and the engagement of learners apart from special inspiration to all the teachers practicing the online teaching learning processes. This mode of application can also be effectively used for reviewing the students' knowledge by formative assessment. 


\section{References}

[1] Vaidyanathan, S. (2013). Fostering creativity and innovation through technology. Learning and Teaching with Technology, 39(6), 24-27. Retrieved from https://files.eric.ed.gov/fulltext/EJ982836.pdf

[2] Barata, G., Gama, S., Jorge, J., \& Gonçalves, D. (2015). Identifying student types in a gamified learning experience.In Gamification: Concepts, methodologies, tools, and applications (pp. 541-558). Hershey, PA: IGI Global. doi:https://doi.org/10.4018/978-1-4666-8200-9.ch0263.

[3] Chadyiwa, M., \& Mgutshini, T. (2015). Using mobile handheld devices as tools of learning and teaching for studentEHPS: A blessing or a curse? International Journal of Humanities, Arts and Social Sciences, 1(2), 8591.doi:https://doi.org/10.20469/ijhss.20005-2

[4] Chang, C. Y. (2017). Autonomy vs. assessment: To what extent the audience approval in a gallery game helps bringpleasure, pressure, and progress. International Journal of Humanities, Arts and Social Sciences, 3(4), 148-156. doi:https://doi.org/10.20469/ijhss.3.20002-4

[5] Chauhan, J., Taneja, S., \& Goel, A. (2015). Enhancing mooc with augmented reality, adaptive learning and gami-fication. In IEEE 3rd International Conference on MOOCs, Innovation and Technology in Education (MITE),Amritsar, Punjab (pp. 348-353). doi:https://doi.org/10.1109/mite.2015.7375343 


\title{
14 \\ Structuring and Implementing the Remote Learning Strategies During Covid-19
}

\author{
B. Anjanee Kumar ${ }^{1, *}$, A. Arjuna Rao ${ }^{1}$ \\ ${ }^{1}$ Miracle Educational Society Group of Institutions, Bhogapuram, \\ Andhra Pradesh, India. \\ *Email: anjanee.rit@gmail.com
}

1. Develop a short-and long-haul remote learning plan. The transient arrangement centers around crisis reaction to keep understudies learning, the medium-term plan gets ready for schools to revive. During this procedure, policymakers ought to counsel outside partners (for example ICT services, communicate controllers/organizations, EdTech new businesses), guaranteeing the fast turn of events and scale-up of the assigned remote learning methodology. Value ought to be a top thought in all arranging endeavors, as the most helpless understudies are most presumably influenced excessively hard and, in all probability, do not have the capacity to get to computerized assets.

2. Create a stock of existing substance to be conveyed by means of remote learning (and plan for how to make extra substance accessible). As opposed to growing new substance, which takes noteworthy time and mastery, center around curating existing (particularly free, 'open') content and adjusting it to the educational plan? For example, more established radio and TV projects might be repurposed. As a rule, substance may originate from various sources; holes and potential duplication ought not out of the ordinary. Later all the while, consider interpreting existing open training assets from different dialects or joining forces with distributing firms that have existing substance.

3. Organize substance to line up with existing educational programs, guaranteeing the learning openings relate to instructive goals. Essentially guiding understudies and educators toward a huge store of materials isn't sufficient; this might be overpowering and reckless. Existing substance ought to be sorted out with the goal that understudies, their parental figures, and instructors comprehend what is accessible and the succession in which it ought to be educated.

4. Utilize instructive radio. This medium contacts a wide crowd and no earlier abilities are required via guardians/understudies. This is especially valuable in settings where other availability alternatives are inaccessible and instruction radio broadcasts exist. In settings where such stations don't exist, starting expenses are high as getting ready substance and adjusting it for a 
radio crowd is time and work escalated, however these costs tighten fundamentally after the underlying scripting is finished. When set up, radio programming plans must be imparted to contact the fitting crowds.

5. Utilize instructive TV. TV is the quickest method to convey address based classes, as top notch educators can be recorded absent a lot of extra preparing. TV can be utilized in different structures, remembering for request (prerecorded exercises) and edutainment. Understudies would then be able to watch chronicles or re-runs of these talks, giving a chance to them to audit or get up to speed on the off chance that they missed anything. This is especially valuable in settings where a large portion of the populace approaches a TV and training channels exist

6. Increase access to computerized assets, by improving network. For nations with the foundation and data transfer capacity, improving network is the initial phase in contacting a huge crowd and relieving access disparities. Joining forces with versatile administrators, telecom suppliers, and different suppliers to build access to computerized assets is a pivotal initial step if a nation is thinking about an on the web.

7. Provide a merged, one-stop-shop to get to content. A focal online entrance can give a combined posting of accessible substance, devices, applications and stages, along with supporting materials and direction for understudies, instructors and parental figures. For example, most colleges utilize their learning the board framework (LMS) as focal stage to communicate,instruct, support, learn, and coordinate different advances, similar to video conferencing, in the LMS.

8. Make substance accessible through an assortment of gadgets. Web based learning devices and stages should run on an assortment of working frameworks and programming applications. Given the close to omnipresence of cell phones in numerous families, and the low accessibility of different advances (particularly work area and PCs), that internet learning openings can be gotten to utilizing cell phones can be basic to guarantee access by the most stretched out conceivable client base.

9. Support the utilization of low data transfer capacity (counting disconnected) arrangements. Commanding that web based learning openings be improved for low data transmission and helpless inertness conditions is fitting. Advancing the accessibility of downloadable instruments and approaches can be likewise very valuable, especially when schools have the way to change over instructive substance into computerized arrangements and burden them onto gadgets.

10. Videos can offer significant learning assets, gave the accessibility of adequate transmission capacity and connecting with content. Basically recording an educator giving a long talk and make it accessible online for understudies frequently locate that lone the most profoundly energetic and drew in understudies can ingest the substance, with constrained effect. Best practice holds that shorter substance is all the more effectively got to by 
understudies.

11. Provide supplemental direction and backing on the most proficient method to utilize and get to remote learning substance to understudies, guardians, and instructors. Just creation content accessible to understudies isn't sufficient. Instructors and parental figures should have the option to handily see how to access and use it. Preferably, families and instructors ought to be given composed direction on the most proficient method to get to content, what related desires are, and where to discover extra data. This data can be imparted through the virtual assistance work area or promoted by means of paper.

12. Use media to share data about remote and internet learning openings. Regardless of whether learning materials are just offered in one manner (for example printed materials, radio or TV, internet learning content, telephone based applications), numerous media stations (counting instant messages) can be utilized to alarm understudies, families, and networks of which materials are accessible and where to discover extra help or direction.

13. Primary. The overwhelming remote learning apparatuses for essential age youngsters are TV, radio, and online recordings. Instructors will in general speak with their understudies through SMS/Social Media. Learning Management Systems can likewise be utilized for correspondence, joint effort, and videoconference encouraged "registrations." More exercises are online for upper essential.

14. Secondary. The transcendent remote learning mode for auxiliary understudies is on the web. In certain nations, radio and TV are utilized to enhance internet learning, and may assume a progressively prevailing job, contingent upon the nation's computerized framework and network.

15. Higher Education. The prevalent remote learning mode for tertiary understudies is for the most part on the web. Commonly, this is encouraged through a Learning Management Systems and coordinated video conferencing frameworks.

\section{Reference}

[1] https://hundred.org/en/collections/quality-education-for-all-during-coronavirus

[2] https://www.amherst.edu/offices/it/academic-technology-services/teachinglearning-covid19

[3] https://en.unesco.org/covid19/educationresponse/solutions

[4] https://www.col.org/resources/keeping-doors-learning-open-covid-19

[5] https://www.indiatoday.in/education-today/featurephilia/story/online-learning-anew-reality-for-schools-during-covid-19-1672523-2020-05-01 


\title{
15
}

\section{Ingenious Approach of Technology Aided Knowledge Transfer in Prodigious Situations}

\author{
N. Arulmozhi ${ }^{1, *}$, K. Baskaran ${ }^{2}$ \\ ${ }^{1}$ Department of Electronics and Instrumentation Engineering, Government College \\ of Technology, Thadagam Road, Coimbatore-641013, Tamil Nadu, India. \\ ${ }^{2}$ Department of Electrical and Electronics Engineering, Alagappa chettiar, \\ Government College of Engineering and Technology, College Road, Karaikudi- \\ 630004, Tamil Nadu, India. \\ *Email: arulmozhi6@gct.ac.in
}

'Engineering is the science, skill, and profession of acquiring and applying scientific, economic, social, and practical knowledge, in order to design and also build structures, machines, devices, systems, materials and processes' (Wikipedia) and therefore by association, anyone who practices engineering is called an engineer. Imparting the outcomes of engineering education in unprecedented scenario had to be seen from the three different perspectives:

- Learner

- Educator

- Bureaucratic

- Employer or Enterprise

\section{Learner's Stand}

Learning isn't a linear process. It is a complex human experience, which had to be exciting and enjoyable. In Indian scenario, a learner's ability to learn is influenced by two factors.

- Intellectual ability

- Financial ability

An analysis of intelligence of the learner is essential to initiate the customised active learning. The learner community is considered to possess any one of the nine types of intelligences namely Linguistic, Spatial, Mathematical or Logical, Intrapersonal, Interpersonal, Musical, Kinaesthetic, Naturalist and Existential [1,2].

\section{Action Points for Learner's stand}

- Social practice activities

- Identifying the intelligence profile of self and ways to enhance.

- Utilizing the resources in a shared and smart forum. 
- $\quad$ Ready to work in teamed situations.

- Learning to groom up from feedbacks -Many students regard feedback on their work as the weakest aspect of their engineering education.

\section{Action Points for Educator's Stand}

- To understand the learning profile and learning capability on a batch of students in a class.

- Framing the learning content according to the learning profile.

- Updated knowledge in framing tools like voice thread, audacity, presentation Tube, Vialogue,

- Developing concept maps for complex learning materials using piktochart for creating Mindmaps.

- Knowledge about free webpage creation tools like wix.

- Creating blogs using edublog.

- Ready to act as a facilitator to bridge the gap between fast and slow learners.

- Choosing Diversified Assessment methods that include class assignments, group presentations, report writing, peer assessment, web-based pre and post learning in the form of problem statements and quizzes.

- Channelizing the present learner's feedbacks to enhance the modules to be improved for future cohorts.

- $\quad$ Recognizing the need to inspire students and develop graduates equipped to meet the growing demands.

- Encouraging Interdisciplinary projects - projects based on the Engineers without borders challenge.

- Developing a Creativity module for Innovation, Enterprise and Ethics.

- Optimizing and integrating the practical teaching resource, combining the social demands and student characteristics.

\section{Action Points for Bureaucratic's Stand}

- Encouraging the widened participation by expanding access facilities to learners.

- Encouraging the individuality of an educator by identifying the skills and promoting the concerned.

- Promoting the content of the educators-made resources in various social platforms.

- Gaining permission to use proprietary softwares, copyrighted materials in building virtual learning platforms.

- The activities of creation and innovation, such as academic competitions, social practice activities, entrepreneurship, making scientific works, training enterprise talents, play important roles of an eminent bureaucracy. 


\section{Action Points for Enterprise's Stand}

- A variety of colorful activities, such as electronic commerce simulation negotiation competition, marketing case analysis competition, entrepreneurship plan competition, robot games and advertising design competition, shall play to be an important carrier for the events of creation and innovation.

\section{Conclusion}

To quote Albert Einstein "We can't solve problems by using the same kind of thinking we used when we created them" and "Insanity is doing the same thing over and over again and expecting different results"

The approaches listed in each of four perspective had to be in a coherent way.

The educator is to believe that there is a need to change with the times and indeed as professionals those strive to do so at every opportunity. Clearly, however the education is defined, it is seen that it is closely related to the concept of learning and learning in a modern classroom has to flow both ways; both educators (teachers) and Learners(students) to aid the intellectual ability of the learner and also to help the financial ability, the bureaucracy and enterprise has to work both ways.

\section{References}

[1] Howard Gardner, Frames of Mind: The Theory of Multiple Intelligence, Basic Books, 1983.

[2] Howard Gardner, Multiple Lenses on the Mind, Paper presented at ExpoGestian Conference, Bogota Colombia, May 25, 2005.

[3] Institution of Engineers Australia. Changing the Culture: Engineering Education into the Future. Engineers Australia: Canberra, 1996.

[4] R. M. Palloff and K. Pratt, how do we know they know? Student assessment on line. 22nd Annual Conference on Distance Teaching and Learning, University of Wisconsin, 2006.

[5] T. A. Chapman, Assessment on line: A four-year retrospective of assessing web-Based student learning. 21st Annual conference on Distance Teaching and Learning, University of Wisconsin (2005). 


\title{
16
}

\section{Challenges of COVID-19 in Higher Education in India}

\author{
Prashant M. Mannikar ${ }^{1, *}$ \\ ${ }^{1}$ Department of English, Dayanand College of Arts, Latur-413531. MS. India. \\ *Email: pmmannikar24@gmail.com
}

\begin{abstract}
Covid-19 pandemic has forced mankind to recast its foundations of life. The unbridled notions of growth and progress that have continued to haunt mankind especially after the industrial revolution during the last decades of the 18th century have caused severe problems for the existence of human life and its bio-diverse framework. Education has always been linked to the human progress and success, usually material one, especially in the post-industrial, imperialistic, and capitalistic world scenario. The education has been seen as an instrument of change in every walk of life. The human societies across the times and space have endeavoured to conquer different forces that govern human life such as the natural forces, economical forces, and social forces. Education, formal or informal, has been one of the key factors in this process. That the education should have inculcated the supreme human values amongst the recipients and learners has been the premise of education systems. But, the supreme human values have been happily forsaken owing to the dictates of extreme commercialization and commoditization of the human transactions. The Covid-19 has put a break on the cut-throat and unruly dictates of progress and success. The education systems have to be reshaped to inculcate the supreme value systems for the conduct of human society. The online platforms and the technological tools have to be used for the teaching-learning process with a keen eye on the up-keeping and strengthening of the value systems.
\end{abstract}

Key Words: Covid-19 pandemic, Social Distancing, Challenges to Education Systems

Education has been the key to the advancement of human society. The education system differentiates the human civilization from other systems of the natural habitat. The transfer of knowledge from the earlier generation to the present generation and from the present to the budding generation in a cyclical process has initiated, sustained and also advanced the development of the human civilization. The calamities and pandemics in the known history of mankind have always made human beings to take recourse to the self, to use the words by Henry David Thoreau. The calamities, natural or otherwise, have offered time to the human society to rethink and redress the course of life. The Covid-19 pandemic has put challenges to 
every field of human activity. The education system, being one of the crucial systems of the human society, has been greatly challenged by the present global pandemic. The challenges can be seen from two major perspectives- the mode of teaching learning process and the rubrics of the education process.

The social distancing warranted by the Covid-19 contagious disease has put challenges to the education systems in India and worldwide. The traditional mode of teaching-learning at all levels, from the KG to PG, would be greatly affecting in the coming times. At present, the entire education system has been on the halt mode. But even after the relief from the tide of this pandemic, one needs to be on guard regarding the usual traditional transactions of the teaching-learning process. The actual face-to-face teaching-learning activities would stand suspended for a considerably prolonged times depending upon the severity of the recurrent eruptions the present Corona virus as well as other contagious diseases especially in the Indian context during the Monsoon period. Obviously, the government, from top to bottom level, would take appropriate preventive measures in ensuring the safety of the agencies involved in the education systems. The student community is the future of the nation in particular and the human civilization in general. So it has to be protected with top priority. Since the education sector is over-crowed, the risk of getting contacted by the life-threatening diseases is higher one. Moreover, the student community may become the potential carrier of the diseases and spread them among the families as well. So the gathering of the student community for the regular traditional classroom teaching-learning as well as other educational activities such as tests and examinations has to be put under strict vigilance and surveillance. The teaching community as well as the non-teaching community involved in the education system also has to be put under strict vigilance. Hence, the alternative modes of teaching-learning process as well as the procedures of the assessment and evaluations have to be devised and implemented for the education process to continue.

The alternative mode of teaching-learning is obviously the technology enabled remote/distance learning. This mode of learning is useful for the synchronous as well as asynchronous learning. The Western and the developed nations have been using this mode for quite a long time. The Indian government has initiated this mode for the prestigious technical institutions and also expanded it in the form of MOOCs offered by the different agencies identified and authorized by the government of India. The UGC, AICTE and other apex bodies monitoring the education systems in India have initiated greater emphasis on the online modes of learning activities. The student community from the metros and other cities has been involved in this process and taking advantages from this platform. But the present crisis has made it customary to take this mode to the remote parts of India. Now therein lay the real challenges for the effective and viable implementations of the online mode of learning process.

The online mode of learning is based on the internet connectivity. The availability, accessibility, and the affordability of the internet connectivity in the small towns and villages is a major challenge for the online learning module. 
Another related challenge is the speed of the internet transmission. In the wake of not having sufficient speed, the learning process gets hampered. The amount of data consumed and the considerable charges to be paid for the data pack also throws challenge for the e-learning mode. The seamless availability of electricity power is yet another constraint to be redressed. The availability, accessibility, and the affordability of the necessary digital tools and gadgets for the effective use of the internet based online learning resources puts yet another challenge for the online learning mode. Apart from these challenges, the competence level of the teacher and the taught community pertaining to the efficient and skillful use of the technology enabled teaching-learning modules is one of the significant issues to address. The government agencies at different levels and the stakeholders of the education systems have to devise viable modus operands for the effective e-learning to happen.

1. The broadband internet connective on the pan-India level. It has to be accessible and at the same time affordable to the student community. The government has to ensure special relief package to address this key ingredient of the online learning.

2. The government has to take care of the provision of the seamless electricity power for the remote areas as well.

3. The technology enabled digital tools like mobile, laptop, smart-board, WiFi modem, personal computers, printers, and LCD projectors need to be provided at the subsidized rates for the stakeholders of the education systems. Special provision has to be made for addressing this significant aspect of the e-learning process.

4. The government has to have MoUs with the providers of the Learning Management Systems like MOODLE or LMS365 for the hassle free access to the teacher and the taught community.

5. Special on hand training has to be given at large scale, especially to the teacher and taught community hailing from remote areas. To insure this to happen, the widespread training centers need to be established. The quality of content and the skill in handling the digital tools on the part of the teacher and the technology-friendliness on the part of the students and the other stakeholders of the education systems is a must for the effective implementation of the e-learning mode of education.

Apart from addressing the physical issues related to e-learning, the stakeholders of education system have to address yet another significant issue pertaining to education system, namely, the very founding principles of the education systems. Education should instill character. Swami Vivekanand categorically emphasized the need of character building through education. The supreme human values like sensitization towards nation, humanity, nature, women and children, prudent moral behaviour, honesty, love, respect for the elders, hardwork, perspiration, and faith in the core human values must be the outcome of the learning procedures. Human resources sans human values can never be the outcome of the education system. The extreme individualistic approach to progress and success achieved through education does not yield much benefit for the social health. 
The recent pandemic has endorsed the fact that group solidarity is the solid foundation of the human society. Mere individual progress in material terms offers neither support nor solace in the times of need as caused by this pandemic. The education systems should work with the aim of socialization and humanization of the human society in its true sense. 


\title{
17
}

\section{Learning Keys During Lockdown}

\author{
S. Muthulakshmi ${ }^{1, *}$ \\ ${ }^{1}$ Department of Civil Engineering, SRM IST, Ramapuram, Chennai, Tamil Nadu, \\ India. \\ *Email: selvigowtham@gmail.com
}

Formal class learning has become an impossible exercise in the teachinglearning process during this COVID-19 lockdown. There are a few major aspects which are to be considered for discovering a teaching - learning frame work for this special term. 'Work from home' concept is generally applicable for the group of professionals who are assigned with specific responsibilities and are ought to abide by their roles to prove themselves at their work place. But this kind of accountability cannot be expected among the young learners.

The second aspect is that though the generation is noticeably better with the usage of technology for their day to day activities, the surge in the usage of internet everywhere and poor internet connectivity in remote places will not help a few group of students to take up a systematic online schedule for learning and assessments. Hence a flexible system of learning is the need of the hour.

Let me put forth a set of simple tips to be followed by the teachers to structure their online teaching:

Any kind of remote teaching - learning process should have two digital education tools. The first tool is required to post materials and assignments by the teacher and to receive timely submissions from the learner. Google tools come in handy for this purpose. The second tool is necessary to conduct live sessions or online classes. Variety of applications are available like zoom, webex etc..

\section{Tip 1}

Whenever you choose an online application consider the compatibility of that particular tool in mobile too since most of the Indian students prefer M-learning. Google classroom provides free service under this category and can be down loaded easily through play store in mobiles.

\section{Tip 2}

Though Google classroom is easily downloadable for access, usage of any digital tool purely depends on the internet trafficking. It is advisable to post all relevant learning resources in the form of pdf, video links, PPTs in the digital platform regular intervals, which is always available for learner's future reference. Also, subject assignments with sufficient duration of deadlines can also be scheduled 
prior to the date and assigned here with much ease.

\section{Tip 3}

Assessments like rapid quiz and short duration tests have to be posted simultaneously via whats app with the class room tools, so that the learners can access them on time through any of the dual platforms. Proper notification on the forth coming test/ quiz has to be given to the students a day before as a precautionary measure in addition to the posting of the assessment schedule in the digital class room.

\section{Tip 4}

Submission of assignments has to be generally accepted through class room tool. Exceptional cases among learners with no access to any of the tools can be allowed to submit through whats app as pdfs which can be archived in the teacher's mail for further grading.

\section{Tip 5}

Proactive learning techniques have to be adapted to bring the learners into the new mode of learning. Short videos (of not more than 3 min) demonstrating a concept can be sent to the students few hours before an online session in which the teacher is supposed to explain the same. This will ease the teacher's work and also induces curiosity among the students. Challenging tutorials can be shared at the end of the session for numerical subjects. Similarly, interesting facts and figures can be shared in between a theory session to retrieve their attention.

\section{Tip 6}

The teachers have to be considerate and flexible in fixing up the submission time for assignments. For eg. the assignment submission time can be announced as 4PM instead of 10 AM. (assignments can be posted accordingly) Similarly the tests can be scheduled by giving them the choice of time in a day. This flexibility approach holds good for online sessions too. Student participation factor is much more important than rigid schedules for an effective learning process.

\section{Tip 7}

Remote learning is more advantageous to learners as they enjoy the comfort of their personal space and time. The comfort factor induces the enjoyment in learning. But ensure that they are responsive during the sessions by making it much more interactive. Always try to give some important announcements/ tips at the end of the session regarding the forth coming assignments. This will hold them back till the end. 


\section{Tip 8}

Always greet them with cheers and appreciate them for their sincere participation. This gesture makes them feel good and confident inspite of the crisis going around. Share a positive message or wish their safety at the end of every online session which keeps them motivated for the rest of the day.

\section{Tip 9}

The continuous absenteeism of certain group of students is quite common for online sessions. Reasons may vary but this problem cannot be discarded. Call them over the phone or send a message to identify their difficulties.Those who are identified with similar learning issues can be grouped together and separate sessions can be conducted and if required these students should be encouraged to attend one to one sessions. Another smart way of learning reinforcement can be done through class ambassadors or student mentors. Mentors can be given responsibilities to monitor and help a smaller group of slow learners.

\section{Tip 10}

Always be responsive to the queries sent by the students. Being accessible and approachable are the magic tools which will make the learners realize that their participation is an important concern irrespective of their grades and will be more supportive towards the learning process.

As we know this lock down is an unusual situation where the excitement of a holiday is missed by the students due to the intervening pressures the emotional quotient of the learners should also be taken care of. Hence, I conclude, only an empathetic approach with due flexible considerations can guarantee an effective teaching - learning process during this period of crisis. 


\title{
18 \\ Teaching and Learning Software Environments Under Open Educational Resources
}

\author{
Lalit Bhanwrela ${ }^{1, *}$, Pritesh Kumar Jain ${ }^{1}$, Sandeep Kumar Jain ${ }^{1}$, \\ Mohit Khamele ${ }^{2}$ \\ ${ }^{1}$ Shri Vaishnav Vidyapeeth Vishwavidyalaya, Indore, M.P. India. \\ ${ }^{2}$ Shri Govindram Seksaria Institute of Technology and Science, Indore, M. P \\ *Email: lalitbhanwrela@svvv.edu.in
}

\begin{abstract}
With the recent developments in the technological devices and availability of higher speed internet connections the online learning processes become very popular nowadays. Due to this MOOCs, open online learning process gained more attention and such open educational resources preferred by students as well as professionals. Also, different online learning platforms motivated academicians \& educational policy makers to discuss on the preparations \& implementation of OER (Open Educational Resources) at all levels. Basically, OER emerges as an educational movement that primarily utilizes different technological tools for the development of e-learning contents and access of these e-learning materials over internet. Through this research we presented an advanced approach for the teachers or educators for the effective utilization of available software technological tools or online environment for the development of OERs and sharing of OERs with students which will help them to engage all students while they are at home during this COVID'19 epidemic.
\end{abstract}

\section{Introduction}

Theoretically OER $[1,2]$ configured as the educational resources which includes literature contents in the form of video lectures, notes, quizzes, and many more e-learning materials available online to access privately or publicly over internet. In the present scenario most of researchers \& educators are working on the design and development of the OER platforms or software environment that can allow the users or learners to learn and collaborate with the educators/ teachers over internet. In context to the technological trends and characteristics that includes higher quality of transmission signal, ease of accessing the network, availability higher configured devices and advanced applications or platforms which integrates all these together to serve the students. 


\section{Design and Development of OER's-}

In order to design and develop open educational resources we need to follow certain standard procedures with effective utilization of the technological tools. For example, MOOC (Massive Open Online Course) is one of the examples of OER wherein students, educators and professionals can learn any particular subject or topic over internet. There are various software platforms or web applications available who offer MOOC's regularly wherein user can get video lectures, notes, and other theoretical e-learning materials however using such open learning environment user can enhance knowledge by interacting with eminent academicians. There are various useful links or web-portals available that offers MOOC's for example, SWAYAM PORTAL, MITCOURSEWARE, IITBOMBAYX, eDX, Spoken tutorial etc. All such web-portals are available on internet and anyone from anywhere in the world can access it to learn particular course at their own. In particular, to develop the e-learning materials or any OER the developer needs to prepare the content in softcopy with the help of some software tools. In particular case Google Classroom [3] a free or open web application developed by Google for educators or teachers involved in teaching at school level or higher level. The purpose of this software environment is to offer a simplify solution in the development of OER and proper sharing of documents between teachers \& students over internet. It can be used as one of the software environment where anyone can create an online class and connect all the respective students in the class through their emails. In addition to this creation of online assignment, live chat, video contents and other e-learning contents can easily be prepared and shared with the students on single click. As we all the impact of COVID'19 in the world due to which most places are in locked down conditions, therefore it becomes important to engage students in various learning process or environment over internet. We have already discussed about the various OERs and particularly MOOCs offering websites in previous paragraph however our intention in this research is to demonstrate a software tool or environment by which educators or teachers can engage their students to complete the required academic course in the current session.

\section{References}

[1] Ameil, "Identifying barriers to the remix of translated open educational resources", The International Review of Research in Open and Distance Learning, Vol. 14 Issue 1, Page No. 127-144.

[2] Acker, F.V., Vermeulen, M., Kreijns, K., \& van Buuren, "The role of knowledge sharing self-efficacy in sharing Open Educational Resources", Computers in Human Behavior, Vol. 39, Page No. 136-144

[3] www.classroom.google.com 


\title{
19
}

\section{Innovative and Effective Teaching Strategies for Online Education}

\author{
Mayuri Kundu ${ }^{1}$, Argha Sarkar ${ }^{2, *}$ \\ ${ }^{1}$ Department of CSE, Vishnu Institute of Technology, Bhimavaram, India \\ ${ }^{2}$ Department of ECE, Vishnu Institute of Technology, Bhimavaram, India \\ *Email: argha15@gmail.com
}

\section{Introduction:}

The Internet has expressively polished our lives specially communication, sharing and accessing data, and expedite information. It is also observed that students are becoming more tech-savvy and interested to participate in the online platforms. Moreover, the COVID-19, pandemic has raised the need of online teaching-learning. It has resulted in most of the academic institutions to shut all across the world. Globally, it has become very important to fix some new online teaching strategies over billions of learners who are out of the classroom.

\section{Important Consideration for Setting Up Effective Strategies:}

Online teaching can help in terms of outcome of the teaching learning process by ensuring Increased flexibility of time, Increased flexibility of location, Context, Information sharing, Online resources, Access, equity \& disability, Digital information literacy, Administration etc. While setting up the new strategies it is crucial to take care the five restrictions (i) Access to technology, (ii) Access to the Internet, (iii) Ability to use technology, (iv) Isolation and (iv) Information overload [1].

\section{Effective Strategies for Online Teaching:}

Cooperative Learning: In our society no one can survive alone, cooperativeness of the members of a group can help them to achieve their goals and survive in difficult situations. Cooperative members of a group not only achieve their goals but also find out the most optimized way to reach the goal.

In classrooms, teachers have to devote much effort and time to make connections between their students and the study materials (eg. Books, notes etc.) and also communication between teacher students takes lots of effort from both sides. Whereas, communication among students is quite easy but always ignored in terms of the teaching-learning process. How a good teacher implementing intraclass interaction can greatly impact on students who are growing in their respective fields? Till the mid-1960s, cooperative learning was an unknown term for educators. 
Elementary, secondary, and university teachings are concentrating on individualistic and competitive learning. However, thought and educational practices have changed. Now cooperative learning is accepted and widely practiced in all levels of education sectors. It is implemented among all ages of students whether in schools or universities. There are two types of cooperative learning: 1. Formal Cooperative Learning 2. Informal Cooperative Learning

In the recent scenario, cooperative learning needs to be implemented in the online platform also. The situation, technologies are enabling the teacher-student communication virtually. It is very important to keep students engaged during these virtual classes by ensuring the desired outcome. Cooperative learning can be implemented in virtual or online classes. So in this way, student's involvement can be increased and communication will be both ways during online sessions. For example, one problem or small project can be allotted to 2-3 students and thus communication between students will be increased as well as they will learn to work in a group while they will be physically away but working as a team.

This is how collaborative learning can be implemented not only in classrooms but also in virtual or online sessions.

Google Class Room: Google Classroom is the most ignored feature provided by Google. It is a free product that can be easily accessed by any user through their g-mail account. It is developed to maintain the communication smooth between teacher and students in terms of sharing notes assignments etc. Students can have discussions over any problems assigned to them. The teacher needs to create a virtual classroom and invite students to that classroom and gradually they can be involved in the activities which are happening in that classroom. It is an easy way to keep track of the progress of a particular student. As institute can register for free Google App for education account, which enables them to have some more features in the google classrooms which are not found in personal google account.

Quick tips about the uses of Google Classroom: Google gives a teacher to create different classrooms for different classes she/he takes from the same google account. It is few clicks away and very easy. In the students, section teachers can view all the students in the class. Either teacher can add students manually or they can join the class by using their own google account. A code will generate when classroom created and that code will be shared among the students. Students can join the classroom by using that code from their laptops, desktops, etc. from their google account. Teachers can choose to give privilege to the students to comment on the shared assignments or even only students can be privileged to do so. There will be a stream section where the teacher can find the assignments, announcements, and questions that he /she has created.

During this online teaching-learning era, google classroom can be very helpful to reach the students and make them more productive by assigning them assignments, tasks through this easily accessible platform.

Innovative Idea for Online Class: As we all know in the online classroom's teachers are getting very little chance to interact with the students which 
were an easy activity during the regular classroom lectures. Online lectures need to be interesting and interactive both at the same time. The teacher can make it fun by arranging some passing question games where the teacher will ask a question to a particular student and after solving and discussing that question that particular student will ask a question to a fellow classmate. This process will be followed until all students have not participated in this game. And finally, the teacher will have a question bank which consists of different types of questions and moreover prepared by students. This type of activity will increase the student's involvement in a virtual classroom and also grow some challenging mentality. Each of the students will get a chance to show their potential by solving the question given by their friends and also by setting a question for his/her friend.

\section{Conclusion:}

Implementation of the discussed techniques may increase the effectiveness of the Online teaching learning process.

\section{References}

[1] E-materials "Introduction to online learning", https://sites.google.com/a/hawaii.edu/new-de-faculty-orientation/Step-1 


\title{
Modernization in Learning Practices \& Also Innovative Teaching
}

\author{
K. Sumanth Ratna ${ }^{1, *}$ \\ ${ }^{1}$ Department of Mechanical engineering, karunya Institute of Technology and \\ Sciences, Karunya Nagar, Booluvampatti, Tamil Nadu, India. \\ *Email: princeratna2017@gmail.com
}

\section{Innovative Teaching}

Teaching means engaging others to gain knowledge \& broaden their mindset in technical way or Non-technical way. As a teacher we must not only propose the information to the students which is available in the Text-books, but also by introducing some extra information. Base information like history, discovery, Inventor etc.., in that specific topic. For this kind of teaching we can use Power-point Presentations, Some Animation clips etc..,

When we come to technical way of teaching we have to use Real apparatus in the class room itself, Showing them and explaining it to students it could more graspable to every single student. Giving them some ideology on the applications where \& how it could be useful. How it's going to have impact in the future technology so, all these explanations, presentations might improve the curiosity of student to learn more about it.

Encouraging the student is first thing in at all time. Either he/she is capable or not in your subject. By supporting \& cheering them-up at all times so that it will increase their morale. And also empower them to conduct seminars, workshops, Q \& A sessions in your department by then it improves them their leadership abilities, team co-ordination.

One of the most important thing for teachers is to follow the punctuality, Non-bias behaviour. He/She has to interact with every single student \& has to understand their way of thinking ability so that we can introduce new interesting \& innovative thinking sessions in the subject period itself.

Socializing, Interaction with students, logical thinking, creating new problems \& resolving every social issues by making new products which could help our community in Rural \& Urban areas by using think out of box.

By understanding the student psychology then we can behave \& guide him/her under any circumstances.

One of the crucial thing in every teacher is language $\&$ also the confidence the base of every teacher feedback is also based on these two factor also. So, improving the confidence in their area when they are taking class in that particular subject will make students to get interested.

By giving social awareness to the student make them realise real time/live 
problems of the community. And also make them to visit the Industries so they get more interested they will get hand-on-experience too. Visitation of, various Tribal/Rural areas and also having campaigns then they will be aware of types of problems in society/ community then they will come up with various innovative ideas to re-solve the problems by the guidance of their faculty and also it will increase their practice in real life technical and non-technical experience.

Encourage every individual student to attend the Conferences, by attending it and presenting will give them confidence, self-ability and be fearless in the stage also.

Join in a various organization, Community forums because of all these makes them to get the new ideas to develop themselves in the current community and society.

Assigning them various projects in the subject which they are interested in and also make them to do experiments in laboratories without technician interruption but by under his surveillance so it gives them hands on experience. then, they can increase their practical knowledge.

Virtual classes play a tremendous role in teaching. Starting new Application(app) which could be easy accessible to every single student from anywhere. It helps the student who didn't attend the classes on that particular day so, that they won't lack their study schedule. This would help them to cop-up with normal students.

\section{Learning Process}

Learning is a keen process of obtaining knowledge from various platforms means of virtual way, physical way etc.., Now a days world is transforming from traditional teaching to Virtual teaching. It is based on the individual ideology of all students but in here there should be a proper guidance to reach out their selfassessment.

Every faculty has to understand the student psychology on the accordance of it they have to behave with students. There will be 3 types of students 1 . Fastlearner 2. Medium-learner 3. Slow-learner by then assign them assignments which could help them to understand, memorizing the subject. Make your class as friendly environment so that every student could feel your class as the best in of other classes.

By then conducting Quiz, Q \& A sessions live interaction during teaching so it will helps students to memorize easily.One of most important part is timings either it would be morning / Afternoon. Basically, Morning sessions (effective time) will be active sessions so, the problematic/Application subjects can be taught in the morning so the remaining electives can be considered for Afternoon session (Noneffective time). There should be no clumpsy in the subject. When the theory classes are being taught same as parallel way there should be practical work so it will be the easy access for students to understand the concepts easily. 


\title{
21
}

\section{Effective and Innovative Online Teaching}

\author{
Preeti Sharma 1, \\ ${ }^{1}$ Babu Banarasi das Engineering College, Lucknow, Uttar Pradesh. \\ *Email: preetisharma2005@gmail.com
}

\section{Introduction}

The recent coronavirus epidemic has pushed all universities and schools to encourage their professors and educators to adopt online teaching as this is likely to continue for quite some time which is bit far in future.

As it is said that any unprecedented times bring along with them huge set of opportunities, therefore this is a golden time to learn and enhance skill within our comfort zone with good exposure to new technologies. In past technologies like online meetings were used by only a small segment of society like IT professional, corporates etc. But now a day it is an essential skill to adopt and work from home for all professional.

Online teaching has become more important and seems to be new normal. The availability of Online Collaboration tools has proved to be catalyst for the education ecosystem in adapting to this new normal of online teaching. These ready to use tools have ensured minimum interruption to the continuity required for curriculum for students and educators. It did not allow us to think about the absence and void which would have existed and the discontinuation that would have happened if such pandemic would have happened few years back.

We have much to learn about teaching and learning, and specifically about teaching and learning in the online environment.

It's no secret that effective teachers are paramount to effective learning in the classroom, and in the case of online studies, the teaching principles and methods they use are even more important.

Yet even with numerous benefits, online educators and administrators have identified various area of opportunities to overcome and improve in this new way According to the recent feedback from professors and students, it is impossible for online teaching to completely replace in-class teaching, however the proportion of online teaching in future education is bound to increase exponentially and its importance will also increase. After doing some research and survey with students I would like to discuss praiseworthy aspects and shortcomings of virtual classes.

\section{Benefits}

1. Online learning ensures effective utilization of time.

2. It is more constructive and collaborative learning. 
3. Learn with the comfort of being safe at home, both for faculty and student.

4. Students who actually want to learn can pay attention without any disturbance.

5. Easy to record, refer learning again and again

6. Ease of sharing notes, ideas and submission of assignments

\section{Challenge}

As many of the professors and students are new to whole online experience. Here are some of the problems, for which we need to find some potential solutions.

1. Network Performance (Speed and Reliability)

2. Students do not learn effectively due to lack of concentration and interest.

3. Learning new ways of effective communication in the online scenario

4. Training and acclimatization of faculties in these new online tools.

5. Infrastructure at remote places in town or in villages.

\section{How to make online teaching more effective.}

Teaching online isn't like teaching in the classroom. It requires a different approach and specific online teaching strategies to boost learning. In a digital learning environment, you often have limited time to make sure that your instructions are precise and effective. No matter your audience, you have to provide maximum value. Need to make teaching interesting and should be delivered in interactive way.

1. We should make us well equipped (proper training) before taking class.

2. Active participation of students must be part of lecture with regular learning check i.e. can have small quizzes and polls in between.

3. Can divide class in small groups for tutorials so that every student can get involve while solving problems.

4. Repeated assessments and grading must be part of course and answers should be discussed with students.

5. Develop a set of explicit expectations for your learners and yourself as to how you will communicate and how much time students should be working on the course each week.

6. Design the learning in small modules so learners gets a sense of accomplishment on completion and stay interseted.

7. Use synchronous and asynchronous activities.

8. Search out and use content resources that are available in digital format if possible.

9. Combine core concept learning with customized and personalized learning.

10. Plan a good closing and wrap activity for the course.

\section{Conclusion}

While conventional classroom teaching or learning have dominated past 
years, online learning which is building stages are growing in popularity and are presenting unique advantages that should be considered. The most important and effective principles for online learning to grow and continue in the new world of digital classrooms are to make them more effective and interactive.

\section{References}

[1] Smith, K., "Toward an Understanding of Training to Teach Online: A Review of the Literature", Pearson Efficacy \& Research,2016, https://www.pearsoned.com/9-strategies-for-effective-online-teaching/

[2] Reas Ricky, "Ten Best Practice for Online Teaching", Tommorow's Professor Posting by Standford University, https://tomprof.stanford.edu/posting/1091.

[3] Huili Han ," How to make the switch to online teaching more effective", 21 March 2020 ,University world News, https://www.universityworldnews.com/post.php?story=20200317134745462

[4] Cooper Scott," 10 Best Practices To Be An Effective Online Teacher", Elearning Best Practices, September, 2016, https://elearningindustry.com/10best-practices-effective-online-teacher.

[5] Alexander Melody W.,Truell Allen D.,Zhao Jensen J., "Expected Advantages and Disadvantages of Online Learning: Perceptions From College Students Who Have Not Taken", Issues in Information Systems, Volume 13, Issue 2,2012, pp. 193-200 


\title{
22
}

\section{Innovative Teaching and Learning Process during COVID 19}

\author{
A.A. Mariena ${ }^{1}$, M. Uma Maheswari ${ }^{1}$, Jinsa K Joy ${ }^{1}$ \\ ${ }^{1}$ Department of Computer Science, Little Flower College, Guruvayoor, India. \\ *Email: aloormariena@gmail.com
}

\begin{abstract}
In the recent time human being become vulnerable to Covid-19 and the entire world is in lock down. This sudden spread of Covid-19 affected the face-toface academic delivery of all higher educational institutions. Hence there is a room for further innovative technologies for effective learning management. Many universities are decided to shift the physical education system through online mode due to sudden arrival of Covid-19. During this lock down period Faculty members are enabled to explore the usage of online courses for learning, teaching and professional development and also build their capability to plan, design and implement online courses that are in tune with international standards. This will help them to manage their curriculum and also in extending effective support to the students in terms of improved learning and communication.
\end{abstract}

Keywords: Online learning, online education, higher education, Covid-19, student evaluations.

\section{Introduction}

Countries around the world face critical challenges due to the rapid development of technologies and the need to have a clear vision of the role that teachers have to play in connecting the power of innovative ICT techniques in the classroom and beyond. One key lesson is to acknowledge the many aspects that ICT in Education policies have to control teacher competencies, learning materials, ICT equipment, and student - teacher motivation. Adopting innovative techniques in Education Master Plan can help countries to successfully address all relevant dimensions [1]. In this context, the ICT Competency for Teachers should be improved in order to help countries to develop in a wider way. Knowledge and information have become key drivers behind development of our nation. Innovative technologies in education enables the students from small villages to acquire quality education with less money. Covid-19 provide vast opportunities for everyone to learn and apply information in their daily lives. [1]. 
The faculties should cope-up with the sudden change in the education system. Students are always in the online world so there won't be any struggle for them to cope up with this online mode of teaching. Many higher education institutions conducted online classes, and online examinations through internet during this lock down period. Most of the academicians across higher education institutions agree that there is a need for developing standardised online education platforms that leads to continuous practise for the teachers and students because all teachers and all students are not well equipped with online tools and methods. Online education is transferred to students through MOOCS (Massive Open Online Courses) and through Zoom sessions. MOOCS are rapidly gaining popularity not only amongst students but also among faculty members because it helps them in their professional development and also gives them the flexibility to study as per their own convenience and time. Online courses serve as a bridge between the teachers and the learners and fill the gap for the off-site learners. It is a great initiative to provide blended learning for millions of students and teachers across the globe. MOOCs create the opportunity for sharing the ideas and knowledge and also helps improve lifelong learning skills by providing easy access to global resources. This requires high-speed internet and education delivery platforms for education institutions and at the same time for students to attend the pre-recorded classes. Higher education is not a topic delivery system, rather, it provides experience that moulds a student to become an active member of the society with full of knowledge and values and it also includes interactions, broadening of ideas, free-flowing open discussions, debates, and mentoring. The National Programme on Technology Enhanced Learning (NPTEL), a project of "NPTEL has grown since it was started, but the level of percolation was only decent. In the past six years, we have explained to people what it means to use online education, and tried to break down their inhibitions. Now, because of Covid-19, there is no option but to adapt and utilise online education".

\section{Effective Online Tools for Teaching and Learning During Covid-}

\section{9}

Google Classroom, Zoom and Edmodo are some commonly used learning platforms during covid-19. Each tool is explained briefly here. Google Classroom manages a virtual classroom and it assists the teachers to establish communication with the students. Using the classroom, the teachers can easily share their course material with the students. This service can be accessible anytime from anywhere across several devices. It also supports assessment through assignments and quizzes. It provides a platform to create, distribute and grade digital assignments. Students can view the assignment given by the teacher and can edit their own copy and submit [2]. They can also upload an external file for evaluation. Students' progress can be tracked through assignments, quizzes and questions, the teachers can grade the students and track their progress. The teachers and students can easily communicate via discussion forum and posting comments. Each new 
material posted is notified to the students. Gmail can also be used for communication, through which alerts are sent relating to new materials, assignments being posted or release of scores and also for posting comments to a student.

Zoom is a cloud-based video conferencing software with a desktop client and a mobile app available across various platforms. It provides an easy-to-use interface for the users to meet online and collaborate on projects when in-person meetings aren't possible. With Covid-19 pandemic, necessity to go online has never been more. Zoom allows its users to virtually collaborate/meet with each other, share content, and continue with their daily workflows with minimum disruption. Zoom offers one-on-one meetings, group meetings, and webinars through a wide range of plans. Zoom meetings can be joined via a web-based device or can be dialled in via a phone. It provides a lot of settings to safeguard your privacy and data. Edmodo is learning platform with more than 85 million users. Here students can communicate with teachers. Teachers can evaluate the progress obtained by the students and track their subject knowledge through assignments and quizzes.

\section{Pros and Cons of Online Education}

Online education permits the teachers to use innovative methods for teaching with the help of technology and online tools and it also reaching out a large number of students across the world. The smart students and backward students take their own time to listen the recorded classes depending on their calibre. Each student can listen the class based on their active time. The students who are unable to join top institutions can attain quality education through online education. At the same time online education has its own drawbacks. First of it takes more effort in terms of time and practise. It could not achieve the face to face experience in learning and it avoid open discussion and mentoring happened in the live class room. Not every student has a good technological facility like computer or fast-streaming internet at home. This leads to issues with attendance and participation in online sessions. It is also stressful to look at the phone or computer screen all day long.

\section{Responsibilities for three parties}

Institutions must have a teaching plan and a reliable technical delivery system and students are frustrated when there are IT issues. There should be a centralized tech system in place that both students and faculty may rely on. The institution should show an interest in the faculty by actually reviewing instructional materials periodically while minimizing their reliance on student's evaluations. Instructor evaluation should be based on the syllabi, the lectures, the assignments, the materials used to enhance the course, the assessment methods used in the course and samples of the student's work, that have been graded by the professor.

Faculty should ensure daily communication with the students. They should

provide feedback in a reasonable efficient time. They should express high expectations and embrace cultural diversities. The assignments should cause students to engage in research, discuss the course material with others and force them to take 
an analytical approach. Exams should always be timed allowing no more than 2 minutes' maximum per question Students should make strongest effort in an online class. Students should be self-motivated and operate as self-directed learners. Students must take Online Education seriously and apply themselves accordingly. Students must realize that they will not benefit from the least amount of work possible.

\section{Conclusion}

Online classes have become the norm in today's times and present all teachers with the splendid opportunity to engage the students in the setting of a virtual classroom. Online classes can to some extent replicate our physical classrooms and provide an enriching teaching and learning experience. Covid-19 enabled the faculty members across the country to develop and manage classes for their students in online mode. Hence, Covid-19 brought positive impact in the education field.

\section{References}

[1] http://www.unesco.org/new/en/communication-andinformation/resources/publicationsand-communicationmaterials/publications/full-list/unesco-ict-competency-framework-for-teachers/

[2] https://en.wikipedia.org/wiki/Google_Classroom 


\title{
23
}

\section{The key Element of online Teaching Learning Experiences}

\author{
Ashish S. Bhaisare ${ }^{1, *}$ \\ ${ }^{1}$ Department, Electronics and Telecommunication Engineering, College of \\ Engineering and Technology, Shahapur, Asangaon, Dist. Thane, Maharashtra - \\ 421601, India. \\ *Email: bhaisare.ashish@gmail.com
}

As the interest for online projects has expanded in the course of recent decades, senior members and division seats frequently incline toward their workforce and are relegated to online courses absent a lot of help or preparing.

Most organizations perceive the requirement for time and backing, yet the device is getting simpler to utilize and for the most part progressively boundless, assisting with picking up time and figure out how to show on the web and reproduce a course for new online situations.

Troublesome the current framework of staff training on the web incorporates the accompanying key employees:

A tenured employee with many years of showing experience; The Assistant Professor faces the need to educate, explore and satisfy residency prerequisites; An undeveloped employee with no overwhelming showing trouble; And at some point partner with a hint of substance ability and instructing experience.

Note that the rundown of blended advanced situations is kept up as indicated by four primary components of the showing experience: - Learner, Faculty Mentor, Content and Environment and Assessment Elements.

\section{The Job of the Staff Movements to All the More Training, Coaching and Tutoring.}

Rather than making fifty-minute talks in another advanced, twenty-firstcentury condition, teachers can help with short idea presentations and difficulties, idea centered conversations, observing conversations, arranging understudy communications, and building up understudies' inventive work. Stands. [1] It is progressively successful to follow understudies 'own reasoning and request by conversing with peers and drenching themselves in assets, as opposed to tuning in to the conveyance of materials from the educator for quite a while. In many talks, students are excessively detached for significant level learning (McKeechy, Pintrich, Lynn, and Smith, 1986; Wyman, 2008; Savinike and Machi, 2011). This change implies that as a teacher you don't possess to save energy for a live talk. Get ready short talks and asset contacts where your training time is recorded or composed, 
making solace and network building encounters and observing and directing understudies' learning encounters [2].

\section{Practitioners Are Increasingly Dynamic and Direct to Their}

\section{Own Learning Encounters.}

Albeit course configuration is a significant impact on how understudies effectively direct their own learning, online course configuration puts a high need on understudies' decision and individual learning choices. Students need to think, compose, do, share, reflect more, Cooperation and audit as a major aspect of the student's locale. Understudies frequently come to grounds class without finishing understanding errands and anticipate that the teacher should let them know, which spares their time. Specialists can't latently stow away in an online course. Professionals are in this manner spurred to finish the readings so as to discuss well with others. This change implies that personnel ought to make gatherings with viable reactant conversation inquiries before the course starts.

\section{Content Resources Are Flexible and Virtually Infinite}

The principle qualification for on the web and mixed courses will in general be that understudies in on the web and mixed courses likely utilize a more noteworthy assortment and sourcing of substance assets. This trademark has advantages and disadvantages for all understudies. Self-coordinated understudies have more opportunity, in spite of the fact that not really more opportunity, to look out and utilize content assets that help successful structure of their own insight base. Likewise, as substance assets are presently progressively portable, assets are open on Smartphone's, iPods, tablets, and other little, cell phones. This implies students have a lot a greater number of alternatives than in the past regarding when, where, and with whom they take a shot at course objectives. An excessive amount of adaptability can be overpowering, so building up a week by week musicality with ordinary, thorough achievements is basic.

\section{Learning Conditions for Social Occasion and Exchange with}

\section{Intermittent Coordinated Gatherings.}

Since online conversations are offbeat and require students' remarks and proclamations, there is a desire that students think about what they have gained from the asset tasks before they come to class (on the web) to partake in the course exercises, for example, posting their appearance in the conversation regions. Online study halls currently give chances to simultaneous social affairs, however great online practice utilizes these get-togethers for accord building conversations, question and answer meetings, peer investigates, community oriented venture work, and introductions anything that is less intelligent work. 


\section{The Evaluation is Continuous}

Assessment in online courses ought to be nonstop, duplicate with network input as opposed to roundabout, and spotlight on singular workforce discourse (Molem, 2005). Assessment of any course improves when teachers become more acquainted with the students as people and invest energy in training and tutoring [3]. In on the web and blended course structure, understudies are additionally alluded to as students and advantage from different understudies 'learning work. Most online course assessments are not shut book tests so stalling isn't required, which disposes of the entire scope of possible difficulties.

There are four elements to each learning experience with a learner at the center

- The student is at the focal point of the instructing and learning process.

- Faculty instructor who coordinates, underpins and assesses the student.

- Content information, abilities and perspectives to the student Development and securing.

- Learn the earth or setting where the student is encountering Learning occasion.

Professionals bring their very own and modified information, aptitudes and ways to deal with learning experience

The objective of any learning experience is for the student to be the place they are. Each student's mind is as close to home and one of a kind as his fingerprints and DNA. It is accordingly difficult to develop a genuine attitude in our students. We will probably build up a massively assorted, inventive brain with basic human discernment, experience and redundancy of feelings.

\section{References:}

[1] Svinicki, M., \& McKeachie, W. J. (2011). McKeachies teaching tips: Strategies, research, and theory for college and university teachers (13th ed.).

[2] Wieman, C. (2008). Science education in the 21st century: Using the tools of science to teach science.

[3] Moallem, M. (2005). Designing and managing student assessment in an online learning environment 


\title{
24
}

\section{Scope for Bridging Industry-Academia Gap During Covid-19}

\author{
V. K. Bupesh Raja ${ }^{1,}$, Pushkaraj D Sonawane ${ }^{2}$, K. Palanikumar ${ }^{3}$, \\ Eriki Ananda Kumar ${ }^{4}$ \\ ${ }^{1}$ School of Mechanical Engineering, Sathyabama Institute of Science and \\ Technology (Deemed to be University), Chennai - 600119, India. \\ ${ }^{2}$ School of Mechanical Engineering, Dr. Vishwanath Karad MIT World Peace \\ University, Pune 411038 India. \\ ${ }^{3}$ Sri Sai Ram Institute of Technology, Chennai, Tamil Nadu 600044, India. \\ ${ }^{4}$ Federal Technical and Vocational Education and Training Institute, Ethiopia. \\ "Email: bupeshvk@gmail.com
}

\section{India Under COVID 19 Lockdown:}

Newly found virus is causing a Coronavirus disease (COVID-19). The disease is mostly transferred over drops caused when an diseased individual coughs or exhales. To tackle this pandemic, the largest COVID-19 national lockdown has been implemented in India.

Due to lockdown, everything has stopped including education sector. Many Indian Universities opted for online mode of education by taking lectures and lab sessions online. Every University or Institute has used innovative Teaching and Learning Process during COVID-19.

\section{Effect of Lockdown on Industry and Academia:}

Faculty group with learners and scholars is known as Academia. The maximum main segment of a study organizations is its teaching. Most of the organizations have really extraordinary high-end applied options which is the topic that appeals the industry. Industry looks for human resource with proper dimension of knowledge in the field [2].

The place where economic activity of manufacturing items or services are there is known as Industry. From raw matter to final products are made in a chain in the industry. Industries, the countries they exist in, and the economies of those countries are interconnected in a complex web of interdependence [3]. Engineering financial sections are divided into four major groups: raw material abstraction, handling goods, delivery of factory-made commodities and information industry.

Proper education is to be given to trainees for solving practical problems faced by industry. Industry academia relation role is played by trainees. If more students are involved with industry related problems during education, this gap 
reduces [4].

Knowledge revolution is taking place from industrial revolution and knowledge economy is moving forward from industrial economy. Global economies are gradually getting interconnected in this changed situation, crossing the national boundaries.

Due to COVID-19 Lockdown, the interaction between Industry and Acdemia has stopped, which is not the healthy sign for both Idustry as well academia.

\section{Innovative Tools to be Used to Bridge the Gap between Industry and Academia:}

\section{Virtual Internships:}

Due to COVID-19 Lockdown, the role of the university has become very dynamic and entrepreneurial in this lockdown period. When intern gets the knowledge and skills working from remote and not physically working at job location is called as Virtual internship.

Mostly, Virtual Internship involves internships in IT related industries, software improvement, advertising, public media, investigation, literature, broadcasting, media, pre- and post-event preparation, video making and correcting, person supplies, detailed project, search engine optimization and advertising, nonprofits and administration positions, party-political placements, business internships, and image management internships. At present these opportunities are very less, but will grow in future.

\section{Collaborative Research Through Digital Platforms:}

Research involving the use of information and communication technology for development inhabits an interdisciplinary space characterized by various philosophies, aspirations, realities and priorities. With COVID-19 pandemic, Collaborative research is gaining its importance.

\section{Developing Industry related Online Courses:}

In Lockdown period, many industries have started the Online Courses from their experts for freshers. Even some of the courses were arranged for advanced users from industry. COVID-19 was used as opportunity by training seekers to hone their skills and expertise for Industrial environment.

\section{Skill development Programs through Virtual Labs:}

As technology and software become more prevalent in our lives, training priorities are shifting to include more marketable technology skills, and also can be used. 


\section{Webinar Series of Experts in a Particular Domian:}

Seminars and conferences are good opportunities for sharing and discussing new insights and networking with peers and can be considered as scientific meetings, and is an enriching experience for students. However, with COVID-19 Lockdown, prohibitive traveling costs and increased logistics, it is not always feasible to organize and attend numerous regular seminars or workshops. In a progressively interrelated domain carried about by technical progressions in telecommunications, additional substitutes can be useful to complement the in-person involvement.

Now a day the limitations of physical places and facilities can be overcome with webinars as they can contain extra applicants than a physical seminar space can accommodate. Webinars offer applicants the handiness of joining an educational demonstration from the ease of their workplaces or houses while multi-tasking. A popular webinar conference is intensely supported on the preparation actions before the session.

\section{References:}

[1] Souvik Sen, Sourav Ganguly and Joyjeet Sen, "Bridging the Industry-Academia Gap and Knowledge Management:Need of Hour", Conference Paper Paper ID2009894, January 2015, pp1-5.

[2] Sodi Jasbir kaur, "Need For Bridging The Industry-Academia Gap", International Journal of Engineering Development and Research, Volume 5, Issue 4, 2017, pp. 1-13.

[3] Johanna Wallin et al., "Bridging the gap between University and Industry: Three Mechanisms for Innovation Efficiency, International Journal of Innovation and Technology Management, Vol. 11, No. 1, 2014, pp. 1-18

[4] Abdullah Al-Shehri et al., Bridging the Gap between University and Industry:Efforts Made at Faculty of Engineering - Rabigh -Saudi Arabia, International Conference on Advanced Information and Communication Technology for Education, 2013, pp.448-456. 


\title{
25
}

\section{Industry and Academia Strategic Partnership for Skill Improvement with Multidisciplinary Method in Engineering Education a Novel Approach Afterward Covid-19}

\author{
A.V.N.L. Sharma ${ }^{1}$, P. Vijaya Kumar ${ }^{2}$, V.K. Bupesh Raja ${ }^{3, *}$, Pushkaraj D \\ Sonawane ${ }^{4}$ \\ ${ }^{1}$ Dean Academic, GIETU, Gunupur \\ ${ }^{2} \mathrm{COE}$, GIETU, Gunupur, \\ ${ }^{3}$ School of Mechanical Engineering, Sathyabama Institute of Science and \\ Technology (Deemed to be University), Chennai - 600119. India. \\ ${ }^{4}$ School of Mechanical Engineering, Dr. Vishwanath Karad MIT World Peace \\ University, Pune 411038 India. \\ *Email: bupeshvk@gmail.com
}

\begin{abstract}
:
Industry and Academia's Innovation and Collaboration Perspectives is need of the hour, putting together imagination, skills, and capital, by transforming challenges into opportunities to create a global economy. The strategic partnership between industry and the Academy needs to be stepped up to go beyond traditional funding for strategic research projects, etc. Indian universities must be at the forefront of pioneering such partnerships in order to become world-class research universities and to create engineers for the future to lead the world with advanced technologies. Industries and universities need to work in synchronization with each other to increase knowledge limits, to become a powerful driver of innovation for technological growth. New technologies at a rapid pace in industry transformation can be generated by a strategic strategy of prosperous, long-lasting cooperation. The critical collaboration will extend the role of research with universities in the years to come and position them as a center of excellence in addressing social and economic growth challenges.
\end{abstract}

Keywords: Strategic partnership 1, multidisciplinary research 2, university leadership 3, 1P 4.

The strategic collaboration goal is cooperation towards R\&D and creativity. Partnerships start with a small and strongly organized approach in most cases, creating challenges for dealing with the strategic opportunities and fostering 
technology talent through investments in cutting-edge research for industrial and academic development. Techno-democrats and academics are engaged in independent projects, from exploratory research to projects and the knowledge of state-of-the-art technology developments. Two organizations' partnerships with large system contracts are establishing joint ventures to satisfy each other's needs for engineers and researchers. Working together increases the practical perception and importance of the exchange of information, technical innovations, and IP. Leadership must have a climate of trust to ensure that business and universities are in good relations [1-3].

\section{Strategic Partnership for Skill Development:}

It can work on following parameters [1]:

- The strategic partnership that impacts teaching and learning through gap analysis for skill development.

- The strategic partnership that develops innovative technologies for societal usage

- The strategic partnership, to lead a new dimension for the role of research in university.

- The strategic partnership to develop industry-ready use, engineering graduates.

The strategic collaboration is critical in the production of new skills for highly skilled technocrats of the next generation. The conventional academic approach can be resolved with multidisciplinary research activities involving academicians and industrial scientists to tackle complex technical issues. Identifying new areas of study to develop new courses through multidisciplinary initiatives would provide insight into modernized curricula and skills for potential students, which are required for modern industries, to promote technical competitiveness. Universities are to be selective for developing strategic partnerships, where the industry has to go to university for its product development. Industries require partnership with able and creative universities with innovative multidisciplinary research environment.

\section{University leadership- A vital role:}

University Chancellors need to make strategic partnerships between industry and the university a priority and regular communication for knowledge and discussion with the entire university brotherhood [4]. For objective-oriented results, they need to form a high-level joint Steering Committee comprising senior academics and company executives. The strategic partnership leads to long-term objectives, and the members of the committee should focus on these achievements. The aims of the relationship are to be made clear to the whole team by giving resources to instill a culture for modern science and social growth. Some core industries may not have qualified managers who can understand both IT and the business aspects of international collaboration. Training of core industry people in 
soft managerial skills, teamwork skills, and entrepreneurial skills gives an edge for the success of an overall project manager. University research culture is to be conducive to collaboration with industries through training classes, workshops, and Soft skills training by universities for a long term association.

\section{Multidisciplinary Research Approach:}

In collaboration with multidisciplinary university training programs, business executives benefit from groundbreaking approaches for emerging technologies [5]. Multidisciplinary academic programs, through interaction with industry, promote talented engineering graduates, and make them prepared for the sector. For multidisciplinary projects, students will develop partnerships with industry. Partnership with industry will lead to new business culture and expand beyond conventional academic curricula. For the success of industry-academic collaborations, the right people with a cross-disciplinary approach are crucial.

\section{Conclusion:}

- The relationship between industry and academia and innovation is focused on viewing the sector rather than the source of funding as a private partner.

- Extensive and creative industry-university collaborations will speed up innovation and help to find solutions to current and potential social challenges.

- In partnership with industry, the research university's mission must be redefined as its strategic partner to develop a new dimension of innovation in the 21 st century.

- In a strategic partnership with industries, academia can expand its position beyond conventional education and public service research to push technology with economic development.

- Present universities adopt a higher education model that has been evolving over the last ten years and needs to be revamped with a focused vision to produce highly qualified professionals with global standards.

- The universities in the 21 st century should be viewed, not just as a generator of ideas but as a source of knowledge and competence in association with industry that can benefit society.

\section{References}

[1] Magennis, S. and McMullin, B. eds. AISHE International Conference: Teaching and Learning in the Changing World of Higher Education. August 2007.

[2] David L. Bain, Michael Brenowitz, Christopher J. Roberts 'An Opportunity for Industry-Academia Partnership: Training the Next Generation of Industrial Researchers in Characterizing Higher Order Protein Structure' Journal of Pharmaceutical Sciences, In Press, Corrected Proof, Available online 23 September 2016 
[3] D. Juedes; J. Krone; M. Sitharam 'Bridging the gap between theory and practice by promoting a partnership between industry and academia' Frontiers in Education Conference, 1999. FIE '99. 29th Annual Year: 1999, Volume: 3 Page: 13C5/19 vol.3, DOI: 10.1109/FIE.1999.840437 IEEE Conference Publications

[4] Julia A. Haller 'Strengthened ties between industry and academia are historical, productive, and crucial Original Research Article Survey of Ophthalmology' Volume 59, Issue 3, May-June 2014, Pages 348-353

[5] Jasmina Berbegal-Mirabent, José Luís Sánchez García, D. Enrique RibeiroSoriano 'University-industry partnerships for the provision of R\&D services' Original Research Article Journal of Business Research, Volume 68, Issue 7, July 2015, Pages 1407-1413 


\title{
An Innovative Practice for Interactive learning process during COVID-19
}

\author{
K. Sunanda Ratna ${ }^{1, *}$ \\ ${ }^{1}$ Department of Electronics \& Communications Engineering, \\ Sri Padmavathi Mahila Viswavidyalayam, Tirupati, Chitoor dist, Andhra Pradesh. \\ "Email: ratnakeerthi2018@gmail.com
}

\section{Innovative Teaching:}

The most critical aspect of creating a prosperous country is education and the principal functions of teachers are to make that happen by making a student into an effective professional person who can change the country's future. Due to COVID-19, all educational institutions have been shut down worldwide. the educational institutions finding the best way to quickly assess teaching through various social media platforms. Teachers seek to discover various new creative ways to teach students following guidance from the higher authority.

Teaching is synonymous with providing facts to students and presenting it. A teacher will be given a lot of research during such a pandemic. Because teachers practice conventional teaching methods at most educational institutions even though online education (e-learning) is offered. Students were primarily distributed to different locations (home). It is like a challenge to the teachers. We may try linking all students at any given time, but not in one location, by using accessible technologies. And by interactive media, we will try to illustrate topics.

The instructor wants to train the students online in different ways. Some students typically have little experience in online learning. We can make the student interested in online learning, by using slides, power points, animation images, the teacher will simply give knowledge and illustrate the content, making the idea easier for a student to understand. And don't attempt to ask questions in online sessions because a student may lose interest in online learning. Interaction of what the teacher's definition describes. That method of instruction will help the instructor, i.e. how a pupil will comprehend what the instructor discusses about the idea and how much they have learned during the lesson. Using Mobile Messaging, teachers may use different social media channels to exchange data on a specific subject or program in a PDF-style, paper file. And we will even ask the student to provide input(feedback) on teaching online so that teachers will seek an upgrade, prepare themselves and to enhance the learning of their students. The creative lesson helps students to grasp the idea as we use the PPTs, maps, circuit charts and so on and not the abstract mind of the student's idea. 


\section{Learning Process:}

Training is just as important as teaching, and we should be careful about that. Since we need not single-way information transmission, but we need two-way information transmission to make it usable for our hard work. To make sure the student learns, we will conduct certain tests but because of the present situation, it is not necessary to carry out a pen-paper exam. So we can check different options, e.g. by splitting students into classes by roll number or names by assigning the specific assignments to the group of students; we may determine separate responses or solutions for the same problem. To encourage students to improve their way of thinking, an online quiz may allow the student individually to do study work to react to teachers' questions and it may enhance student awareness and can raise student interest in the subject. This is mostly that it makes the pupil gain insight from teachers, think differently and become better than before. The key component in learning is the great student-teacher relationship. Therefore, student-teacher interactions are key benefits of this online learning process. Via these social media sites, they will independently lift their viewpoint and concerns or questions. While traditional realistic teachers can find it challenging, it also allows the instructor to learn new subjects to upgrade themself and answer student questions. So as a result, the instructor must relearn, recover the experience and become a new individual. Therefore, the definition required specialized methods and sophisticated strategies to teach through creative learning activities. As a result of the closure of educational institutions, some websites offer free training classes to enable teachers to increase their skills \&ability, and the improvement of a teacher's skills is really important as well. So a professor has to learn his students' psychology in different ways to understand the idea. As there are slow learners, average learners and fast learners in a class, we will do some research to make the slow student the same as other students. to interact with slow learners through the various principle. If they still do not understand the issue, we will take a while to describe the same topic in another way with teaching aids. This would be useful for slow-learning students and medium-learning pupils. We might also seek the assistance of fast students to explain the concept to slow students because perhaps certain students are introverted and, while they do not understand the concept they may not utter a word so that we can communicate with class members to know the actions of slow students to assist them in their studies. By means in a variety of ways, we can persuade students that learning is not a challenge but instead a way of thinking and incorporating tools and strategies in real-life circumstances. 


\title{
Advantages of Online Classes During Covid 19
}

\author{
C. Daniel ${ }^{1}$, J.B. Renin Jeya Gem ${ }^{2,}{ }^{*}$, P. Mounica ${ }^{2}$ \\ ${ }^{1}$ Karunya Institute of Technology and Sciences, Coimbatore \\ ${ }^{2}$ Cape Institute of Technology, Levingipuram \\ *Email: reninjohnselvan18@gmail.com
}

\section{Advantages of Online Classes}

- The online classes will help students to come on time

- To ask more doubts and more interactive than class

- The voice of the professor can be audible to everyone

- Submission of assignments made simple

- Conducting online events like quiz can help students to enhance the knowledge

- Sharing notes

- The student's attendance can track easily

- Class timings can be adjustable

\section{What Should Have Before Starting Online Class}

- Strong Internet connection

- Proper sound system (microphone)

- The virtual conferencing tool software should be installed by all students

- Each student should have a note pad 


\title{
Teaching learning practices during lockdown
}

\author{
J. B. Renin Jeya Gem ${ }^{1,{ }^{*}}$, P. Mounica ${ }^{1}$, C. Daniel ${ }^{2}$ \\ ${ }^{1}$ Cape Institute of Technology, Levingipuram \\ ${ }^{2}$ Karunya Institute of Technology and Sciences, Coimbatore \\ *Email: reninjohnselvan18@gmail.com
}

\section{Do's and Don'ts of effective classes in online Dos}

- The phone number and mail id of all students should be collected and create a what's app and learning management group

- Before taking online class, using offline several time you should prepare and take class

- Camera, computer, microphone, Wi-Fi connections should be checked properly before the session

- The assignment questions should be prepared before the online classes

- Easy week two or three students can volunteer to inform the timing of all students this session so that the workload of the faculty is reduced

- Encourage to ask doubts related to subjects in online

- Post the assignments just after your session and announce the details in your session.

- The assignments should be posted online in each session with last date notification

- Each weak take a feedback from students through google forms to improve in teaching practices

\section{Don'ts}

- Don't be formal as usual in offline class

- Don't cancel or change the timings of classes very often

- Don't take class more than 30 minutes 


\title{
A Study on Organizational Commitment Factors on Burnout among private school teachers in Kodaikanal
}

\author{
M. Banumathi ${ }^{1, *}$ \\ ${ }^{1}$ Department of Business Administration, Govt. Arts and Science College for \\ Women, Kodaikanal, Dindigul, Tamil Nadu, India. \\ *Email: srigurubanu1977@gmail.com
}

\begin{abstract}
The main aim of this research is to find out the effectiveness of organizational commitment on burnout among private school teachers in Kodaikanal. Simple Random Sampling was performed to collect the sample. Total sample size was 100 and regression was performed to measure the relationship. The findings of study extend our understanding of influencing organizational commitment factors on burnout among private teachers in Kodaikanal. Private teachers' organizational commitment is reducing the burnout. Research findings point out that most of the factors are reducing the burnout.
\end{abstract}

Keywords: Organizational commitment and burnout

\section{Introduction}

Burnout is considered as an extended reaction to continual emotional and interpersonal stressors in work. It is defined with the help of three dimensions, which are inefficacy, cynicism and exhaustion (Leiter, M.P., 2003). Role stress is one of the main predictor of burnout. The stress among employees leads to problems in domestic and social life. The employees who have the feeling of burnout are often separated and have low level of satisfaction in the work. Burnout among employees lead to emotional disorders and pessimistic attitudes towards the job they are working in (P.Balathandayutham, 2019).

\section{Review of literature}

Kashifa Yasmin and Prof. Dr. Najib Ahmad Marzuki (2015) had examined the $\mathrm{OC}$ and job burnout among the psychiatric nurses of Punjab, Pakistan. One of the serious issues in the Asian countries is the increasing problems of job burnout. This study was based on the casual turnover model and had examined the influence of OC on job burnout. The survey of the study was cross sectional. Data was collected from 305 nurses belonging to psychiatric hospitals of Punjab, Pakistan. The 
objectives of the study were accomplished by employing structural equation modeling. The findings of the study showed that the burnout of the nurses was influenced only by normative commitment. On the other hand, affective and continuous commitment had no impact on their burnout.

Reza Rezaee Shirazi, Yaghob Beiki, Faezeh Zamanian, Kamal Esapour (2011) had studied the relationship between OC and job burnout amongst the physical education teachers of Golestan province, Iran. The aim of this study was to examine the relation between $\mathrm{OC}$ and burnout. The data was collected using a questionnaire. The sample respondents were the teacher of physical education in Golestan Province. The sample size of the study was 216 teachers. In this research, Organizational Commitment Scale (Allen and Meyer, 1990) and Maslach Burnout Inventory had been used. These outcomes will be argued in more detail regarding the negative relationship between burnout and OC as well as better conditions of official teachers and their greater commitment.

\section{Research Methodology}

The teachers of the private school in Kodaikanal were taken as the sample population for the study. The size of the sample was fixed at 100 for the purposes of the study. To select the sample for the study, the technique of simple random sampling was adopted. Responses from the employees were gathered with the help of a questionnaire regarding burnout. Likert scale was being used to collect data, where 5 rating is strongly agreeing and 1 rating is done for strongly disagree.

\begin{tabular}{|c|c|c|c|c|}
\hline \multicolumn{5}{|c|}{ Analysis and Interpretation } \\
\hline R & R Square & Adjusted R Square & F & Sig. \\
\hline $.972(\mathrm{a})$ & .945 & .941 & 227.926 & $.000(\mathrm{a})$ \\
\hline
\end{tabular}

\begin{tabular}{|l|l|l|l|l|l|}
\hline \multirow{2}{*}{} & \multicolumn{2}{|l|}{$\begin{array}{l}\text { Unstandardized } \\
\text { Coefficients }\end{array}$} & $\begin{array}{l}\text { Standardized } \\
\text { Coefficients }\end{array}$ & t & \multirow{2}{*}{ Sig. } \\
\cline { 2 - 6 } & $\mathbf{B}$ & $\begin{array}{l}\text { Std. } \\
\text { Error }\end{array}$ & Beta & & \\
\hline (Constant) & .462 & .091 & & 5.071 & .000 \\
\hline Affective commitment & .185 & .033 & .208 & 5.659 & .000 \\
\hline Continuance commitment & .085 & .039 & .118 & 2.207 & .030 \\
\hline Normative commitment & .064 & .033 & .095 & 1.959 & .050 \\
\hline
\end{tabular}

\section{a) Dependent Variable: Burnout}

It shows from the results of multiple regressions that dependent variable is influenced by the independent variables. To check whether this $\mathrm{R}^{2}$ is statistically significant, ANOVA is performed. The F value obtained is $227.926(\mathrm{P}<0.000)$ and hence it is concluded that the factors are significantly influences the burnout. It is deduced from the coefficients table. This table provides the regression analysis that among the three independent variables taken for the study, factors are significantly 
influence burnout. The coefficient is positive which would indicate that antecedents are associated to organizational commitment decreases the burnout.

\section{Discussion}

It is also inferred that the all the organizational commitment factors predicts burnout. Job commitment much required to be considered while analyzing and predicting the burnout in future. Right flow of burnout is required to make up with job commitment and proper guidance of execution.

\section{Conclusion}

Based on viewpoint of the burnout model, this study provides experienced support for an extended report of influencing organizational commitment factors on burnout among private teachers in Kodaikanal. The findings of study extend our understanding of influencing organizational commitment factors on burnout among private teachers in Kodaikanal. Private teachers' organizational commitment is reducing the burnout. Research findings point out that most of the factors are reducing the burnout.

\section{References}

Kashifa Yasmin and Prof. Dr. Najib Ahmad Marzuki (2015) Impact of Organizational Commitment on Intention to Quit Among Psychaitric Nurses: Evidence from Pakistan, International Journal of Learning \& Development, Vol. 5, No. 4. 89-102.

Reza Rezaee Shirazi, Yaghob Beiki, Faezeh Zamanian, Kamal Esapour (2011) The relationship between organizational commitment and job burnout amongst the physical education teachers of Golestan province, Iran, Australian Journal of Basic and Applied Sciences, 5(10): 1379-1384, 2011

P.Balathandayutham,(2019) Impact of Organizational Conflict on Burnout: a study with special attention to Chennai city. Vol-5 Issue-6 2019. 1680-1683.

Leiter, M.P., 2003. Coping patterns as predictor of burnout the function of contra and escapist coping patterns. Journal of organizational behavior. 